\title{
Through a GlaSS DARKLy: The ROLE AND REVIEW OF "NATIONAL SECURITY" CONCEPTS IN CaNADIAN LAW
}

\section{CRAig Forcese*}

The expression "national security" or its close similes lacks a precise meaning, even in the public policy literafure. Nevertheless, the concept appears in over 30 federal statufes. In most instunces, the term is undefined, an important oversight in light of the significant powers these statutes accord the government. Under these circumstances, how courts revien' government invocations of "national security" is of real importance. With some exceptions, courts applying s. 7 of the Charter and standard administrative law doctrines have accorded substamial deference to government nutional securify deferminations. When largely deferential subsiantive review of the ambiguous concept of national securit! is coupled with the ex parte and in camera context in which these cases are offen heard, the net effect is to leave government with a freer hand in national security matters than in other domains of administrative decision making. Several possible responses to this problem are proposed.
Il manque un sens precis à l'xpression a scicurifé nationale nou toute similinde proche, mème dans les documems porfom sur la politique ginerale. Níammoins. te concept apparait dans plus de 30 lois féderales. Dans la phupart des cas, le terme n'est pas defini, omission importantc à la lumière des pounoirs considerables que ces lois conferent au gowernement. Dans ces circonstances, la manière que les cours revoient les imocations gowernementes de la " securite intionale" est dimportance réelle. Sauf quelques excoptions. les cours appliquant larticle 7 de la Charte el les doctrines habituelles dit droit administratif on confere' une defercence considirable anx deferminations de securife nationale dn gouvernement. Lorsque letude substantive exsentiellement de deféronce du concept ambigu de securite nationale est jumelice di un concept cx partc et in camera, ce qui est souven le cas de ces causes. te gouvernement a alors des coudces plus franches en termes de securite nationale que dans dautres domaines de prise de dicisions administratives. Plasieurs riponses eventuclles à ce problime som proposices.

\section{TABI.E OF CONTENTS}

I. INTRODUCTION . . . . . . . . . . . . . . . . . . . . . . . . 964

Il. Defining "National SeCurity" . .................... 965

III. National SEcurity In CANAdian Statutory LaW ........... 968

A. Classification of National Security Provisions . . . . . . . 968

B. ASSESSMENT .......................... 979

IV. Judicial Treatment of Nationai. Security Provisions . . . . . . . . 981

A. COURT SCRUTINY OF NATIONAL SECURITY DECISIONS

IN ADMINISTRATIVE LAW .................... 982

B. COURT SCRUTINY Where Fundamental JUSTICE

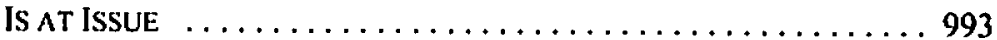

C. AsSESSMENT ........................... 998

V. Conclusion ............................... 999

Assistant Professor, University of Ottawa, Faculty of Law. B.A. (MeGill), M.A. (Carl.), LL.B. (Ottawa), LL.M. (Yale), member of the Bars of Ontario, New York and the District of Columbia. My thanks to the editors of the Alberta Law Review and to my colleagues Joseph Magnet and Ruth Sullivan for their comments on this article. 


\section{INTRODUCTION}

United States Senator William Proxmire once commented that "[p]ower always has to be kept in check; power exercised in secret, especially under the cloak of national security is doubly dangerous."' The basis for Proxmire's fear is clear: national security imperatives may render the exercise of power particularly inscrutable and unaccountable.

In Canada, this issue is now regularly in the public eye, especially in venues such as the public inquiry into the involvement of Canadian officials in the maltreatment of Maher Arar in Syria. At the time of this writing, that inquiry was awash in government claims to secrecy. These assertions - motivated by repeated references to "national security" - have prompted the Commission's counsel himself to express frustration with the government's understanding of national security. ${ }^{2}$ Meanwhile, the CEO of the Canadian Newspaper Association complained publicly in 2005 that Ottawa may be invoking national security to stave off disclosure of information needed to hold the government to account. ${ }^{3}$

At core, these controversies reflect a tension between national security and government accountability. In Canadian law, the legal checks and balances that together render government accountable come in two forms: constitutional limitations and administrative law requirements. Both areas have developed rapidly in the last two decades, constraining government activity in fashions unprecedented in Canadian history. However, the question raised by Proxmire's observation and the Canadian examples noted above is whether the exercise of the state's "national security" powers is swept up by this evolution of legal principle. In other words, where governments purpon to exercise "national security" authority, are they subject to the same judicial scrutiny as when exercising other powers? Or, alternatively, is "national security" a carte blanche for government authority, one that constitutes a de facto "notwithstanding" provision effectively negating application of both constitutional and administrative legal principles?

The answers to these questions are not simply of academic interest. As this article explores, the expression "national security," or close similes such as "the security of Canada," are commonplace in Canadian law, appearing in at least 33 federal statutes. Some of these laws can be described as specialized national security laws, establishing extraordinary government powers to protect against, or respond to, national security crises. Other laws are simply regular statutes covering an array of subject matters in which national security is invoked in a handful of provisions. With few exceptions, successful recourse to

1 This famous observation, made by the venerable Democrat Senator, was invoked in Canada during debate of BillC-55, the Public. Safety Act, which ereated substantial new govemment powers in response to national security concerns. Sec House of Commons Debates, 180 (1 May 2002) at 1710 (Hon. Bev Desjarlais (Churchill, NDP)), online: <wWw.parl.ge.cia/37/1/parlbus/chambus/house/ debales/180_2002-05-01/han 180_1710-E.htm>. The particular power at issuc in this debate - the creation of "-military security zones" in Canada -- was delcted from the bill that was finally enacted into law in 2004. Sec Public Sufety Act, 2002, S.C. 2004, c. 15.

: "Truce over evidence declared in Arar inquiry: But issuc of secrecy remains to be resolved" Edmonton Journal (2 April 2005) A8; Michelle Shephard, "Very private aspects of the Arar public inquiry; Commission counsel frustrated with government secrecy" Toronto Star (29 January 2005) FI.

Anne Kothawala, "Our cloak of secrecy: Threats to press freedom are not limited to far-off lands" Otsawa Citizen (3 May 2005) A17. 
national security concepts in these latter laws enables the government to deviate from the habitual rules set out in the statute. "National security" is structured, in other words, as a legal basis for non-compliance with the regular law.

In light of these potent provisions, whether "national security" is adequately defined and whether courts probe carefully the legitimacy of its invocation are issues of real importance, if only for this reason: at many times and in many countries, national security laws have been employed to suppress exactly the sort of accountability tools - court review, public protest and speech, freedom of the press, transparency, privacy and the like - that protect against government abuse.

This article takes up these issues. Part II very briefly examines the concept of national security and underscores its conceptual ambiguity. Part III discusses and attempts to categorize circumstances in which national security is incorporated into Canadian statutory law. In so doing, it highlights the extent to which national security is poorly defined in statute law. Statutory ambiguily is not unique to national security concepts, and is often cured by recourse to rules of statutory interpretation. However, limiting the deleterious impacts of ambiguity through these and other rules depends on robust judicial scrutiny. For this reason, Part IV focuses on the manner in which key national security provisions have been judicially reviewed. Specifically, the article examines how rigorous courts have been in examining government national security decisions employing standard administrative law doctrines and s. 7 of the Canadian Charter of Rights and Freedoms. ${ }^{4}$ Most of these cases arise in the immigration context. However, the approaches applied by the courts have a likely resonance beyond immigration law.

The article concludes that the invocation of "national security" does not immunize government decision making from court review. Nevertheless, with some exceptions, courts have approached judicial review of executive national security decisions very carefully, extending a large measure of curial deference. While not unique to the national security area, this deference is disquieting; first, in light of the inherent conceptual ambiguities of national security, and second, when considered alongside the unusual procedural context in which these reviews often take place. Specifically, when highly deferential substantive review of an ambiguous term is conducted on an ex parte and in camera basis, the net effect is to leave government with a freer hand in national security matters than in any other domain of government decision making. Put another way, national security is policed by courts, but in a fashion that may leave both courts and outside observers peering through a glass, darkly.

\section{Defining "National Security"}

"National security" is a term familiar to most people. It is, however, a remarkably difficult expression to define. As noted in a recent report published by the Institute for Research on Public Policy, " $[t]$ he term national security is used frequently to refer to matters ranging from 
domestic or internal security through to international security, but is seldom defined."' When some effort is made to set out its content, the definition is often so broad as to be meaningless. For instance, Canada's National Defence College defined national security in 1980 as

the preservation of a way of life aceeptable to the Canadian people and compatible with the needs and legitinute aspirations of others. It includes freedom from military attack or coercion, freedom from internal subversion, and freedom from the erosion of the political, economic, and social values which are essential to the quality of life in Canada.

As should be immediately evident, this definition wraps much of what governments exist to do within the blanket of national security, a fact acknowledged even by those comfortable with this definition.?

A slightly more focused definition of national security has been offered by the U.S. Department of Defense:

National security is a collective lerm encompassing both national defence and foreign relations of the Uniled

Stales. Specifically, the condition provided by:

a) military or defence advantage over any foreign nation or group of nations;

b) favourable forcign relations position; or

c) defence posture capable of successfully resisting hostile or destructive action from within or without, overt or covert.

While this definition is narrower than that from the Canadian National Defence College, it still contains important ambiguities. For instance, litlle that governments do in the area of international relations falls outside national security if the concept includes a "favourable foreign relations position."

Still another definition, one that boils a broad definition of national security into a strategy, is as follows:

Central to [a] kind of national security policy ... [based on the preservation of a way of life acceptable to the Canadian people and the security of people, national inslitutions, and freedoms from unlawful harm, armed atlacks and other violence] are three principal frameworks: deterrence against attacks; delence against those atlacks that you can identify; and then a credible ability to defeat attucks on our national security.

s W.D.Macnamara \& Ann Fity-Gerald, "A National Security Framework for Canada" Policy Malters 3:10 (October 2002) 1 at 7, online: Research-Home <www.irpp.org/rescarch/index.htm>.

Quoled in ibid. at 8.

Procedings of the Standing Committee on Delence and Security, Issuc 6 - Evidence (29 October 2001) 37th Parl., Ist Sess., online: <www.parl.ge.ca/37/1/parlbus/commbus/senale/Com-e/defe-e/06ev-e.htm? Language $=E \&$ Parl $=37 \&$ Ses $-1 \& \mathrm{comm}$ id $=76>$. Evidence of Professor Douglas Bland, Chair, Defenee Management Studies Progrum, School of Policy Studies, Queen's University (indicating that "Iiff a broad delinition of 'national security' is taken, there is a danger that there will be no obvious limits to policy," but then citing with a measure of approval the National Defence College definition). 
This definition has a clear focus on coercive force as a national security threat, limiting the expansiveness of the other definitions. To a certain extent, it presages the bent given to "national security" in the Government of Canada's April 2004 "National Security Policy."10 That document describes "national security" as "deal[ing] with threats that have the potential to undermine the security of the state or society." "The three specific threats the government seeks to address are: first, "[p]rotecting Canada and the safety and security of Canadians at home and abroad" (which includes "protect[ing] the physical security of Canadians, our values, and our key institutions"); second, "[e]nsuring that Canada is not a base for threats to our allies"; and third, "[c]ontributing to international security."'2

While these threat-based descriptions of national security are narrower than others cited above, they are still extremely general. Note the reference to protection of "Canadian values" as a national security objective in the Government's definition. Moreover, the descriptions do little to define exactly when threats of the sort listed in the definitions constitute national security concerns. For example, when is a threat to the physical safety of Canadians a legitimate "national security" concern rather than a regular policing matter?

This issue of national security "legitimacy" was taken up in yet another effort to define national security. In 1995, a group of experts in international law, national security and human rights announced the Johannesburg Principles on National Security, Freedom of Expression and Access to Information. Principle 2 defines "legitimate national security interest." To be legitimate, a restriction invoking "national security" must have as "its genuine purpose and demonstrable effect" the protection of "a country's existence or its territorial integrity against the use or threat of force, or its capacity to respond to the use or threat of force, whether from an external source, such as a military threat, or an internal source, such as incitement to violent overthrow of the government." A restriction is not legitimate "if its genuine purpose or demonstrable effect is to protect interests unrelated to national security, including, for example, to protect a government from embarrassment or exposure of wrongdoing, or to conceal information about the functioning of its public institutions, or to entrench a particular ideology, or to suppress industrial unrest."13

This definition's focus on threats to a country's existence and territorial integrity sets a very high threshold for proper invocations of national security. It would restrict enormously the capacity of states to cite national security as justification for what they do in the military and policing area.

Given these struggles to define "national security," the question to be answered in the remainder of this article is how open-ended Canadian law has been in its efforts to define and oversee reliance on - this amorphous concept. 


\section{National Security in Canadian Statutory Law}

The expression "national security," or close equivalents such as "Canada's security," appear in some 33 federal statutes. Yet, despite its prominence, the legal literature does not currently include an analysis of the scope and significance of "national security" in Canadian laws. For this reason, this article proposes an initial classification and analysis.

Statutes invoking "national security" may be categorized in several ways. ${ }^{14}$ For instance, there are certain laws that clearly have a specialized national security purpose or object. A second broad class of statutes includes those that invoke national security in a handful of provisions, but whose specialized purpose is not national security. Given the extent to which national security concepts now pervade the Canadian statute books, drawing the line between specialized national security laws and more general statutes is difficult.

For this reason, this article proposes classifying statutes, not by their purpose, but by the effect produced by invocation of national security in these laws. Thus, the section that follows categorizes these laws into five "effects" classes: government-empowering effect; punitive effect; information-limiting effect; privacy-limiting effect; and regulation-limiting effect.

\section{A. Classification of National Security Provisions}

\section{GOVERNMENT-EMPOWERING EFFECT}

A number of statutes authorize government action expressly to pre-empt, or respond to, national security concerns. Laws falling into this first category meet two criteria. First, these laws "empower" the government to act affirmatively in a fashion that would otherwise be impermissible. Second, they do not also fall within any of the other more nuanced and specific categories proposed in this article.

Most prominently, the Canadian Security Intelligence Service Act ${ }^{15}$ establishes a spy service whose exact objective is to curb and respond to national security threats. Thus, the CSIS Act authorizes CSIS to compile, analyze and retain information and intelligence concerning activities "that may on reasonable grounds be suspected of constituting threats to the security of Canada." 16 "The potentially open-ended nature of "threats to the security of Canada" is constrained somewhat by the Act itself. Thus, the term "threats to the security of Canada" is defined in the statute as

(a) espionage or sabotage that is against Canada or is detrimental to the interests of Canada or activities directed toward or in support of such espionage or sabotage,

14 For its balance, this article will use the term "national security," although as noted throughout, the expressions actually used in the statute books vary somewhat and include other, similar phrases.

is R.S.C. 1985, c. C-23 [CSIS Act].

16 Jbid., s. 12. 
(b) foreign influenced activities within or relating to Canada that are detrimental to the interests of Canada and are clandestine or deceptive or involve a threat to any person.

(c) activities within or relating to Canada directed toward or in support of the threat or use of acts of serious violence against persons or property for the purpose of achieving a political, religious or ideological objective within Canada or a forcign state, and

(d) activities directed toward undermining by covert unlaw ful acts, or directed toward or intended ultimately to lead to the destruction or overthrow by violenec of, the constitutionally established system of government in Canada. ${ }^{17}$

Obviously, each of these categories of national security threat is broad and vague, and thus capable of expansive definition. On the other hand, much like the Johannesburg Principles, this definition constrains the potential for abuse, not least because of a caveat that expressly excludes "lawful advocacy, protest or dissent, unless carried on in conjunction with any of the activities referred to" above. ${ }^{1 \mathrm{k}}$

At least one other law authorizing unusual government powers on national security grounds incorporates by reference this CSIS $A C l$ definition. Thus, under the federal Emergencies $A c t,{ }^{19}$ the successor to the infamous Wor Measures $A c t,{ }^{20}$ a "national emergency" is "an urgent and critical situation of a temporary nature that ... seriously threatens the ability of the Government of Canada to preserve the sovereignty, security and territorial integrity of Canada and that cannot be effectively dealt with under any other law of Canada." "' One species of "emergency," a "public order emergency," is defined as an "emergency that arises from threats to the security of Canada and that is so serious as to be a national emergency."22 Cabinet may declare a "public order emergency" on "reasonable grounds," triggering significant powers under the $A c t .{ }^{23}$ ".'Threats to the security of Canada" has the meaning assigned by section 2 of the Canadiam Security Imelligence Service Act."

Notably, however, many other laws that authorize special government powers on national security grounds do not define the concept. These laws are set out in the table below.

Ihid., s. 2.

Ihid.

R.S.C. 1985 (4th Supp.), c. 22.

Repealed, R.S.C. 1985 (4th Supp.), c. 22.

Emergencies det, supra note 19, s. 3(b).

Ibid., s. 16.

Ibid., s. 17.

Ibid., s. 16. 


\begin{tabular}{|c|c|c|}
\hline Statute & National Security Provision & $\begin{array}{l}\text { Definition of } \\
\text { National Security } \\
\text { or Its Similes }\end{array}$ \\
\hline $\begin{array}{l}\text { Energy Supplies } \\
\text { Emergency Act }\end{array}$ & $\begin{array}{l}\text { The Act allows the government to establish a program for the } \\
\text { mandatory allocation of petroleum products within Canada } \\
\text { when it believes conservation is required in response to a } \\
\text { "national emergency" stemming from shortages of petroleum } \\
\text { "that affect or will affect the national security and welfare and } \\
\text { the cenomic stability of Canada."25 }\end{array}$ & None. \\
\hline $\begin{array}{l}\text { Nuclear Safery and } \\
\text { Control Act }\end{array}$ & $\begin{array}{l}\text { The } A c t \text { is directed at limiting the risks to, inter alia, national } \\
\text { security associated with "possession and use of nuclear } \\
\text { substances, prescribed equipment and prescribed } \\
\text { information. }{ }^{26} \text { As a consequence, the Canadian Nuclear } \\
\text { Safety Commission created by the } A c t \text { has, as one of its } \\
\text { objectives, the prevention of unreasonable risk to national } \\
\text { security associated with nuclear teclnnology and materials. } \\
\text { To this tnd, the Commission may make regulations } \\
\text { "respecting measures to ensure the maintenance of national } \\
\text { security. }{ }^{28} \text { In the event of an emergency and notwithstanding } \\
\text { any other provision in the } A c t \text {, the Commission has the power } \\
\text { to make any order it considers necessary to maintain national } \\
\text { security. }{ }^{29} \text { In licensing nuclear related undertakings, the } \\
\text { Commission must be persuaded that the applicant will make } \\
\text { adequate provision for national security. }{ }^{30} \text { Inspectors } \\
\text { assessing compliance by the licensee with the } A c t \text { may order } \\
\text { that a licensee take any measure that the inspector vietws as } \\
\text { necessary to maintain national security. }{ }^{31}\end{array}$ & None. \\
\hline $\begin{array}{l}\text { Export and Import } \\
\text { Permits Act }\end{array}$ & $\begin{array}{l}\text { The } A c t \text { empowers the government to control exports of } \\
\text { sensitive materials, including military equipment. Thus, the } \\
A c t \text { allows Cabinet to create an Export Control List "to ensure } \\
\text { that arms, ammunition, implements or munitions of war, } \\
\text { naval, army or air stores or any articles decmed capable of } \\
\text { being converted thereinto ... will not be made available to } \\
\text { any destination where their use might be detrimental to the } \\
\text { security of Canada. }\end{array}$ & None. \\
\hline
\end{tabular}




\begin{tabular}{|l|l|l|}
\hline Statute & National Security Provision & $\begin{array}{l}\text { Definition of } \\
\text { National Security } \\
\text { or Its Similes }\end{array}$ \\
\hline $\begin{array}{l}\text { Civil Air } \\
\text { Navigation Services } \\
\text { Commercialization } \\
\text { Act }\end{array}$ & $\begin{array}{l}\text { In delegating civil air navigation services to NAV CANADA, } \\
\text { the government may direct NAV CANADA to provide civil } \\
\text { air navigation services where, inter alia. "it is in the interest } \\
\text { of national security to do so."33 }\end{array}$ & None. \\
\hline $\begin{array}{l}\text { Public Service } \\
\text { Aabour Relations }\end{array}$ & $\begin{array}{l}\text { The Act indicales that "[n]othing in this Act or any other Act } \\
\text { is to be construed as requiring the employer to do or relirain } \\
\text { from doing anything contrary to any instruction, direction or } \\
\text { regulation given or made by or on behalf of the Govemment } \\
\text { of Canada in the interest of the safety or security of Canada or } \\
\text { uny state allied or associated with Canada.".34 }\end{array}$ & Nonc. \\
\hline
\end{tabular}

\section{Punitive EFFECT}

Several statutes impose penalties or other special disadvantages on persons on national security grounds. Two of these laws include a definition of national security. Thus, the Citizenship $\mathrm{Act}^{35}$ includes a procedure for denying citizenship to persons where, on reasonable grounds, the government believes that the person will engage in activities that constitute a threat to the security of Canada. The term "threat to the security of Canada" is given the same definition as appears in the CSIS Act. ${ }^{36}$

Similarly, the Security Offences $A c t^{37}$ "federalizes" national security offences, indicating that "[n]otwithstanding any other Act of Parliament, the Attorney General of Canada may conduct proceedings in respect of an offence under any law of Canada where ... the alleged offence arises out of conduct constituting a threat to the security of Canada within the meaning of the Canadian Security Intelligence Service Act." 38

Yet, several other very potent punitive provisions do not define the national security expression. For instance, the concept of national security appears in several offences found in the Criminal Code of Canada. ${ }^{39}$ Thus, the offence of sabotage includes property damage done for a purpose prejudicial to the safety, security or defence of Canada, all undefined terms.

Likewise, national security and its similes are not defined in the /mmigration and Refugee Protection $A c t .{ }^{40}$ The $I R P A$ is not intended as a punitive statute, instead fostering the

S.C. 1996, c. 20, s. 24(3).

S.C. 2003 , c. 22 , s. 2 . s. $250(1)$.

R.S.C. 1985 , c. C.29.

Ibid., s. 19.

R.S.C. 1985, c. S-7.

Ihid., s. 2(a).

R.S.C. 1985, c. C -46 .

S.C. 2001 , c. 27 [IRPA]. 
conditional presence of aliens in Canada. Nevertheless, it includes provisions that, in practice, may result in the imposition of special disadvantages on aliens up to and including incarceration where national security concerns are engaged.

For instance, the IRPA denies entry to Canada by a permanent resident or a foreign national for "being a danger to the security of Canada." permanent residents may be detained on entry if the immigration officer "has reasonable grounds to suspect that the permanent resident or the forcign national is inadmissible on grounds of security." National security "certificates" may also be issued by the government, resulting in the detention and possible removal of already admitted aliens. Finally, a person may be deported, even to torture, where important security concerns are engaged. These last two aspects of the IRPA are discussed at greater length in Part IV below.

As the chart below suggests, other punitive laws are equally silent on the scope of national security.

\begin{tabular}{|c|c|c|}
\hline Statute & National Security Provision & $\begin{array}{l}\text { Definition of } \\
\text { National } \\
\text { Securlty or Its } \\
\text { Similes }\end{array}$ \\
\hline $\begin{array}{l}\text { Security of } \\
\text { Information Act }\end{array}$ & $\begin{array}{l}\text { The Act makes it an offence for a person to, "at the direction of, } \\
\text { for the benefit of or in association with a foreign economic } \\
\text { entity, fraudulently and without colour of right," communicate a } \\
\text { trade secret to another person, group or organization or obtain. } \\
\text { retain, alter or destroy a trade secret "to the detriment of" } \\
\text { Canada's, inter alia. national security. }{ }^{43} \text { Under the same } A c t \text {, } \\
\text { persons may be designated "a person permanently bound to } \\
\text { secrecy" if certain senior government oflicials believe that "by } \\
\text { reason of the person's office, position, duties, contract or } \\
\text { arrangement, ... the person had, has or will have authorized } \\
\text { access to special operational information; and ... it is in the } \\
\text { interest of national security to designate the person." } 44 \text { "Special } \\
\text { operational in formation" is a defined term and basically means } \\
\text { military and intelligence-related information. }{ }^{45} \text { Persons } \\
\text { permanently bound to secrecy commit an offente if they } \\
\text { disclose this special operational information, subject to a } \\
\text { carefully defined public interest defence. }\end{array}$ & None. \\
\hline
\end{tabular}

$4 \quad$ ibid., s. 34(d).

$42 \quad$ bid., s. 55(3)(b).

4 R.S.C. 1985, c. O-5, s. 19.

4 ibid., s. 10

43 ibid., s. 8.

to Ibid., ss. 13-15. 


\begin{tabular}{|c|c|c|}
\hline Statute & National Security Provision & $\begin{array}{l}\text { Definition of } \\
\text { National } \\
\text { Security or Its } \\
\text { Similes }\end{array}$ \\
\hline $\begin{array}{l}\text { Charities } \\
\text { Registration } \\
\text { (Security } \\
\text { Information) ACt }\end{array}$ & $\begin{array}{l}\text { The Act creates a procedure for denying or revoking an } \\
\text { organization's charitable status by reason of a connection to } \\
\text { terrorism. It sets out, as its principles, the notion that } \\
\text { "maintaining the confidenec of taxpayers may require reliance } \\
\text { on information that, if disclosed. would injure national security } \\
\text { or endanger the safety of persons" and that reliance on this } \\
\text { information "in determining eligibility to become or remain a } \\
\text { registered charity must be as fair and transparent as possible } \\
\text { having regard to national security and the safely of persons." }\end{array}$ & None. \\
\hline $\begin{array}{l}\text { Nuclear Safety } \\
\text { and Control Act }\end{array}$ & $\begin{array}{l}\text { The } A c t \text { makes it an offence for anyone who "alters, otherwise } \\
\text { than pursuant to the regulations or a licence, or misuses any } \\
\text { thing the purpose of which is to ... maintain national security ... } \\
\text { at a nuclear facility or at a place where, or vehicle in which, a } \\
\text { nuclear substance is located. .'\$8 }\end{array}$ & None. \\
\hline
\end{tabular}

Under the heading of "punitive" provisions, it is also instructive to consider the post-September $1 \mathrm{l}$ anti-terrorism provisions introduced into the $\mathrm{Criminal}$ Code by $\mathrm{Bill} \mathrm{C}-36$, the Anti-terrorism Act. ${ }^{49}$ Perhaps surprisingly, these new Criminal Code sections rarely invoke "national security" or the like. Instead, the Bill C-36 amendments focus on the definition of terrorism, introducing a series of new offences and new state powers where terrorism occurs or is suspected. There is a rich literature critiquing these terrorism provisions, some of it focused on definitional issues. ${ }^{\text {st }}$ A full review of these positions lies outside the ambit of this article. However, it is notable that Bill C-36's Criminal Code changes do rely on the national security concept in one critical area: national security is used, and is left undefined, in sections used to determine the availability of certain extraordinary ex parte and in camera proceedings. ${ }^{\text {s1 }}$ As the next section discusses, Canada's statute books are rich in similar provisions creating special secrecy rules in the interest of national security.

S.C. 2001, c. 41 , s. 2.

Supra notc 26, s. 48.

Bill C-7, An Act to amend the Criminal Code, the Official Secrets Act, the Conadu Evidence Act, the Proceeds of Crime (Money Laundering) Act and other Acts and to enact measures respecting the registration of charities, in order to combat terrorism. Ist Sess., 37th Parl., 2001 (as passed by the House of Commons 28 November 2001).

- See, in particular, Kent Roach, Scptember /I: Consequences for Canada (Montreal: MeGill-Queen's University Press, 2003); Ronald J. Daniels, Patrick Macklem \& Kent Roach, eds.. The Security of Freedom: Essuns on Canada's Anti-kerrorism Bill (Toronto: University of Toronto Press, 2001).

See e.g. Criminal Code, supra note 39, s. 83.05 (providing for the creation of a list of terrorist organizations and a limited right of appeal for inclusion of this list, but also indicating that the court may review evidence or information in this appeal "in the absence of the applicant and any counsel representing the applicunt, if the judge is of the opinion that the disclosure of the information would injure national security or endanger the safety of any person"). See also s. $486(1)$ (indicating that criminal proceedings are open to the public, but permitting a judge to reverse this openness if he or she views it as "necessary to prevent injury $10 . .$. national security"). 


\section{INFORMATION-LIMITING EFFECT}

A number of statutes include specific national security exemptions from the information disclosure regime created by the law. For instance, there are various national security exemptions under the Access to Information $A c t^{52}$ and Privacy Act. ${ }^{53}$ Notably, these exemptions are fairly carefully defined. Thus, the $A c c e s s A c t$ allows the government to refuse release of requested records less than 20 years old containing information prepared by a government investigative body during lawful investigations of "threats to the security of Canada" within the meaning of the CSIS Act. ${ }^{54}$ The Privacy Act contains a mirror provision, restricting a person's access to their own personal information held by the government. ${ }^{3 s}$

Alternatively, in another series of exemptions that the Supreme Court of Canada has characterized as "national security" exemptions, ${ }^{56}$ the government may refuse to disclose any record requested under the Access or Privacy Acts "that contains information the disclosure of which could reasonably be expected to be injurious to the conduct of international affairs, the defence of Canada or any state allied or associated with Canada or the detection, prevention or suppression of subversive or hostile activities." ${ }^{\text {77 }}$ For the most part, these terms are carefully defined. ${ }^{\$ 8}$

In striking contrast, many other important information-restricting laws do not define national security or its similes. Most notable among these statutes is the Canada Evidence $A c t .^{59}$ The $A c t$ sets out important evidentiary rules for proceedings ${ }^{60}$ and contains special rules limiting access during these proceedings to certain sensitive information. Thus, the statute defines "potentially injurious information" as "information of a type that, if it were disclosed to the public, could injure international relations or national defence or national security." "Sensitive information," meanwhile, "means information relating to international relations or national defence or national security" that the Government of Canada is

$52 \quad$ R.S.C. 1985 , c. A-1 [Access $A C t]$.

s3 R.S.C. 1985, c. P-21.

s4 Access Act, supra note 52, s. 16.

ss Privacy Act, supra note 53, s. 22.

* Ruby v. Canada (Solicitor General), [2002] 4 S.C.R. 3, 2002 SCC 75 at para. 5 [Ruby].

"Access ACl, supra nole 52. s. 15. Sete also Privacy Act, supra note 53, s. 21, incorporating by reference s. 15 of the Access $A C$.

38 The term of "defence of Canada or any statc allied or associated with Canada" is defined as including the efforts of Canada and of foreign states "toward the detection, prevention or suppression of activities of any forcign state directed toward actual or potential attack or other acts of aggression against Canada or any state allied or associated with Canada." The expression "subversive or hostile activities" is also carefully defined as

espionage against Canada or any state allied or associated with Canada, ... sabotage, ... activities directed toward the commission of terrorist acts, including hijacking, in or against Canada or forcign states, ... activitics direcled toward accomplishing government change within Canada or foreign states by the use of or the encouragement of the use of forec, violence or any criminal means, ... activities directed toward gathering information used for intelligence purposes that relates to Canada or uny stule allied or associated with Canada, and ... atetivities directed toward threatening the safety of Canadians, employecs of the Government of Canada or property of the Government of Canada outside Canada (Access Acl, supra note 52, s.15(2)).

so A "proceeding" "means a proceeding before a cour, person or body with jurisdiction to compel the production of information." Ibid., s. 38. 
"safeguarding." These terms are not defined in greater detail. The Canada Evidence Act mechanism is described in greater detail in Part IV below.

Other information-restricting national security provisions are outlined in the chart below.

\begin{tabular}{|c|c|c|}
\hline Statute & National Security Provision & $\begin{array}{l}\text { Definition of } \\
\text { National } \\
\text { Security or its } \\
\text { Similes }\end{array}$ \\
\hline $\begin{array}{l}\text { Corrections and } \\
\text { Conditional } \\
\text { Release Act }\end{array}$ & $\begin{array}{l}\text { Under the } A c f, \text { a Correctional Investigator, or his or her } \\
\text { delegate, may disclose information required for his or her } \\
\text { investigation, but may not disclose "information obtained or } \\
\text { prepared in the course of lawful investigations pertaining to ... } \\
\text { activities suspected of constituting threats to the security of } \\
\text { Canada ... if the information came into existence less than } \\
\text { twenly years before the anticipated disclosure.."6? }\end{array}$ & $\begin{array}{l}\text { "Threats to the } \\
\text { security of } \\
\text { Canada" given the } \\
\text { same meaning as } \\
\text { the equivalent } \\
\text { tcrm in the CSIS } \\
\text { Act. }\end{array}$ \\
\hline $\begin{array}{l}\text { OMcial } \\
\text { Langnages } \mathrm{ACt}\end{array}$ & $\begin{array}{l}\text { The Commissioner of Olficial Languages is to "avoid } \\
\text { disclosing any matter the disclosure of which would or might } \\
\text { be prejudicial to the defence or security of Canada or any state } \\
\text { allied or associated with Canada" in his or her annual report to } \\
\text { Parliament. }\end{array}$ & None. \\
\hline Expropriation Act & $\begin{array}{l}\text { Where land is expropriated for "a purpose related to the safety } \\
\text { or security of Canada or a state allied or associated with } \\
\text { Canada" and the public interest so demands, the government } \\
\text { need not provide specifics on this purpose in its notice of inlent } \\
\text { to expropriute. }\end{array}$ & None. \\
\hline $\begin{array}{l}\text { Canadian Human } \\
\text { Rights Act }\end{array}$ & $\begin{array}{l}\text { Members of the Human Rights Commission receiving } \\
\text { information in the course of their investigations are to "take } \\
\text { every reasonable precaution to avoid disclosing any matter the } \\
\text { disclosure of which ... might be injurious to intemational } \\
\text { relations, national defence or security or federal-provincial } \\
\text { relations." Similarly, they are to guard against disclosing } \\
\text { "information obtained or prepared by any investigative hody of } \\
\text { the Government of Canada ... in relation to national } \\
\text { security. "." Moreover. the government may notify the } \\
\text { Commission during its investigation of a complaint that the } \\
\text { practice impugned by the complaint was based on } \\
\text { considerations relating to the security of Canada. In such } \\
\text { instances, the Commission must dismiss the complaint or refer } \\
\text { it to the Review Committec established by the CSIS Act for its }\end{array}$ & None. \\
\hline
\end{tabular}




\begin{tabular}{|l|l|l|}
\hline Statute & National Security Provision & $\begin{array}{l}\text { Definition of } \\
\text { National } \\
\text { Security or its } \\
\text { Similes }\end{array}$ \\
\hline $\begin{array}{l}\text { Canadian Ifuman } \\
\text { Rights Act (con'1) }\end{array}$ & $\begin{array}{l}\text { own review. } \\
\text { cnter premises to investigate complaints may be limited by } \\
\text { Cabinct "in the interests of national delence or security." }\end{array}$ & None. \\
\hline $\begin{array}{l}\text { Environmention } \\
\text { Protection Act. } \\
\text { l9g9 }\end{array}$ & $\begin{array}{l}\text { Information disclosure under the Act is constrained by a } \\
\text { provision indicating that the Minister ol National Defence may } \\
\text { prevent the release of information. "the disclosure of which } \\
\text { could reasonably be expected to be injurious to the defence or } \\
\text { security of Canada or of a state allicd or associated with } \\
\text { Canada." } 68\end{array}$ & None. \\
\hline
\end{tabular}

\section{PrivaCY-Limiting EFFFCT}

The flipside to information-limiting invocations of national security are those provisions allowing select, national security-motivated disclosure of information that would otherwise be protected. National security is defined in one of these laws, the Proceeds of Crime (Money Laundering) and Terrorist Financing Act. ${ }^{69}$ This statute creates a Financial Transactions and Reports Analysis Centre tasked with reviewing financial data for evidence of money laundering and terrorist financing. Information the Centre believes is "relevant to threats to the security of Canada" is to be disclosed to CSIS. "The expression "threats to the security of Canada" is given the same definition as the CSIS Act. ${ }^{71}$

On the other hand, national security is not defined in any of the other privacy-limiting statutes, as the chart that follows suggests.

\begin{tabular}{|l|l|l|}
\hline Statute & National Security Provision & $\begin{array}{l}\text { Definition of } \\
\text { National } \\
\text { Steurity or Its } \\
\text { Similes }\end{array}$ \\
\hline $\begin{array}{l}\text { Immigration and } \\
\text { Refugee Profection } \\
\text { Act }\end{array}$ & $\begin{array}{l}\text { With the cnactment of the Public Safely Act, the IRPA } \\
\text { permits regulations on the disclosure of information related to } \\
\text { national security. }\end{array}$ & None. \\
\hline
\end{tabular}

S.C. 2000, c. 17.

Ibid., s. 55.1.

Bbid., s. 2.

Sitpra note 1.

Supra note 40, s. 150.1 . 


\begin{tabular}{|c|c|c|}
\hline Statute & Natlonal Security Provision & $\begin{array}{l}\text { Definition of } \\
\text { National } \\
\text { Security or Its } \\
\text { Similes }\end{array}$ \\
\hline $\begin{array}{l}\text { Personal } \\
\text { Information } \\
\text { Protection and } \\
\text { Electronic } \\
\text { Documents ACt }\end{array}$ & $\begin{array}{l}\text { An organization otherwise barred from collecting or } \\
\text { disclosing personal information without the consent of the } \\
\text { person concemed may do so if the disclosure is "made to a } \\
\text { government institution or part of a government institution that } \\
\text { has made a request for the information, identified its lawful } \\
\text { authority to obtuin the information und indicated that," inter } \\
\text { alia, "it suspects that the information relates to national } \\
\text { security." An individual whose personal information has } \\
\text { been disclosed may be denied aceess to the information } \\
\text { disclosed. or knowledge of the disclosure, to the government } \\
\text { if the government believes that compliance with the request } \\
\text { could reasonably be expected to be injurious to national } \\
\text { security. }\end{array}$ & None. \\
\hline $\begin{array}{l}\text { Criminal Records } \\
\text { Act }\end{array}$ & $\begin{array}{l}\text { The government may disclose records concerning a crime for } \\
\text { which a pardon has been granted for "any purpose related to } \\
\text { the safety or security of Canada or any state allied or } \\
\text { associated with Canada." }\end{array}$ & None. \\
\hline Aeronautics $\mathrm{ACt}$ & $\begin{array}{l}\text { Airlines flying from Canada and Canadian airlines must } \\
\text { disclose information relating to passengers required by } \\
\text { foreign governments under their own laws. This information } \\
\text { is not to be redirected by the forcign government to the } \\
\text { Canadian government." It may, however, be redirected "for } \\
\text { the purpose of protecting national security or public safety or } \\
\text { for the purpose of defence, ... and any such information } \\
\text { collected by the govemment institution may be used or } \\
\text { disclosed by it only for one or more of those purposes."78 }\end{array}$ & None. \\
\hline Customs Act & $\begin{array}{l}\text { A Customs Officer may disclose customs information where it } \\
\text { "is rensonably regarded by the official to be information } \\
\text { relating to the national security or delence of Canada." }\end{array}$ & None. \\
\hline $\begin{array}{l}\text { Wimess Protection } \\
\text { Program Act }\end{array}$ & $\begin{array}{l}\text { The government may disclose information about the location } \\
\text { or a change of identity of a protectec or former protectec } \\
\text { under the } A C t \text { "if the disclosure is essential in the public } \\
\text { interest for purposes such as ... national security." }\end{array}$ & None. \\
\hline
\end{tabular}

S.C. 2000, c. 5, s. 7.

lbid.s. 9.

R.S.C. 1985 , c. C. 47 , s. $6(3)$.

R.S.C. 1985 , c. A-2, s. 4.83 ,

bid., s. 4.83(2).

R.S.C. 1985 (2d Supp.), c. I, s. 107.

S.C. 1996, c. 15, s. I (3)(c). 


\section{REgULATION-LIMITING EFFECT}

Last, several laws establish a national security exemption from the regular regulatory regime established by the statute. Only one of these statutes provides a (modest) definition of national security. Thus, the Canadian Transportation Accident Investigation and Safety $B o a r d A C t^{81}$ includes a provision restricting the application of the $A C l$ "in the interests of national security as are provided by the National Defence Act or by regulations made under that Act or as the Governor in Council is hereby authorized to prescribe by order." ${ }^{82}$ In fact, this definition provides little clarity. The National Defence Acr does allow deployment of the military in aid of civil power to quell riots or civil disturbances, ${ }^{83}$ but says very little about national security per se.

The other statutes in this category do not define national security, as the table below notes.

\begin{tabular}{|c|c|c|}
\hline Stalute & National Security Provision & $\begin{array}{l}\text { Definition of } \\
\text { National } \\
\text { Security or It: } \\
\text { Similes }\end{array}$ \\
\hline $\begin{array}{l}\text { Canodian } \\
\text { Envirommental } \\
\text { Assessmem Act }\end{array}$ & $\begin{array}{l}\text { The government may make regulations partially or fully } \\
\text { excmpting from environmental assessments projects both in } \\
\text { Canada and outside Canada that "in the opinion of the } \\
\text { Govemor in Council, ought not to be assessed for reasons of } \\
\text { national security." }\end{array}$ & None. \\
\hline $\begin{array}{l}\text { Mackenzie Valley } \\
\text { Resource } \\
\text { Management Act }\end{array}$ & $\begin{array}{l}\text { A preliminary environmental screening of certain } \\
\text { "developments" in the valley need not be conducted where, by } \\
\text { regulation, "an examination of the proposal is declared to be } \\
\text { inappropriate for reasons of national security." } \$ \text { " }\end{array}$ & None. \\
\hline $\begin{array}{l}\text { Comodian } \\
\text { Environmental } \\
\text { Protection Act. } \\
1999\end{array}$ & $\begin{array}{l}\text { Privale individuals may not bring an "environmental } \\
\text { protection action" to enforce environmental requirements } \\
\text { where the activity said to violate environmental rules was } \\
\text { undertaken, inter alia, to "protect national security."86 }\end{array}$ & None. \\
\hline Species at Risk Act & $\begin{array}{l}\text { A person is relieved of the obligation not to harm protected } \\
\text { wildlife or wildlife habitat if that person is engaged in } \\
\text { activities relaled to national security authorized by any other } \\
\text { Act of Parliament. }\end{array}$ & None. \\
\hline $\begin{array}{l}\text { Camade National } \\
\text { Marine } \\
\text { Conservation } \\
\text { Areas ACt }\end{array}$ & $\begin{array}{l}\text { Cabinet may introduce regulations exempting Canadian and } \\
\text { foreign government ships from regulations relating to the } \\
\text { control and management of marine conservation areas "in the } \\
\text { interests of Canadian sovereignty or security...88 }\end{array}$ & None. \\
\hline
\end{tabular}

tbid. s. 3(6).

Sec National Defence Acr, R.S.C. 1985, c. N-S, Parn VI.

S.C. 1992, c. 37, s. 59 .

S.C. 1998, c. 25, s. 124.

Supra nole 68, s. 24.

S.C. 2002, c. 29, s. 83 .

S.C. 2002 , c. 18, s. 17 . 


\begin{tabular}{|l|l|l|}
\hline Statute & National Security Provision & $\begin{array}{l}\text { Definition of } \\
\text { National } \\
\text { Security or Its } \\
\text { Similes }\end{array}$ \\
\hline $\begin{array}{l}\text { Mutual Legal } \\
\text { Assistance in } \\
\text { Criminal Mathers } \\
\text { Act }\end{array}$ & $\begin{array}{l}\text { The Minister of Justice may reluse the enforcement of an order } \\
\text { of forfeiture of property situated in Canada issued by a foreign } \\
\text { eriminal court where the Minisler belicves that that } \\
\text { enforcement of the order might prejudice Canada's security. }\end{array}$ & None. \\
\hline
\end{tabular}

\section{B. ASSESSMENT}

The discussion in this Part suggests that national security is a potent legal concept. National security is obviously the touchstone in many specialized national security statutes, laws that greatly expand the powers of the government either to regulate or penalize. It is also an important feature of more general laws, freeing the government from constraints it would otherwise face under these statutes or expanding the range of powers to which it would otherwise be restricted.

Yet, as the discussion above and the chart below also suggest, the national security expression is rarely defined. Indeed, in the final analysis, only nine of the 33 federal statutes invoking national security - a miserly 27 percent - define the concept.

Frequency of National Security Definitions

\begin{tabular}{|l|c|c|}
\hline Statule by Classification & Total Number of Statutes & $\begin{array}{l}\text { Number of Statutes } \\
\text { Defining National } \\
\text { Security or lts Similes }\end{array}$ \\
\hline Government Empowering Effect & 8 & $3(38 \%)$ \\
\hline Punitive Effect & 7 & $2(29 \%)$ \\
\hline Information Limiting Effect & 8 & $3(24 \%)$ \\
\hline Privacy Limiting Effect & 6 & $0(0 \%)$ \\
\hline Regulation Limiting Effect & 7 & $1(14 \%)$ \\
\hline Total & 36 (in 33 separate statutes) & $9(27 \%$ of 33 statutes) \\
\hline
\end{tabular}

This failure of definition produces Canadian statute books replete with a concept whose precise content is extremely amorphous, even when described by the national security experts discussed in Part II. This ambiguity conveys substantial discretion to the executive branch to define national security as it wills, perhaps not always consistently or properly. The conclusion echoes observations made by other authors, focusing on certain sub-aspects of national security law. Discussing Canada's anti-terrorism laws, Sujit Choudhry and Kent Roach argue that "[i]n the war on terrorism, discretionary powers take centre stage." Similarly, Faisal Bhabha complains that the anti-terrorism law "confers an overly general 
amount of discretion on police and governmental authorities, while it also uses language that is obscure and overly broad." ${ }^{\text {"2 }}$ Lorne Sossin, discussing the concept of "terrorism" and "danger to the security of Canada" found in the then-Immigration Acl, observes that the problem with these expressions "is not their indeterminacy per se ... but, rather that their meaning may change with the political currents of the day.... Statutory terms which authorize state action that may jeopardize the life, liberty and security of the person ... must have some inherent content beyond the particular predilections of particular ministers at particular historical junctures., ${ }^{+13}$

Ambiguity in statutory terms is not unique. Many expressions found in the law books are undefined, and thus open the door to discretionary interpretations. At base these terms may not be infinitely elastic. They may be subject to review and interpretation by courts. A complicated series of statutory interpretation rules may dispel - or at least limit ambiguity. Put succinctly, in modern statutory interpretation, "there is only one principle or approach, namely, the words of an Act are to be read in their entire context and in their grammatical and ordinary sense harmoniously with the scheme of the Act, the object of the Act, and the intention of Parliament. ${ }^{\text {"94 }}$ This precept - and the more specific approaches that flow from it - help courts breathe meaning into statutory expressions that otherwise defy easy definition. ${ }^{95}$ Indeed, as the discussion below notes, the Supreme Court in Suresh ${ }^{96}$ assigned some meaning to national security concepts in at least one context - immigration law. Irremediably ambiguous terms, meanwhile, may be struck down by courts as unconstitutionally vague, where their use infringes on life, liberty or security of the person.97 Ambiguity is not threatening, in other words, so long as the ambiguous term is subject to searching judicial review. As the Supreme Court has observed, "[j]udicial decisions may properly add precision to a statute. Legislators can never foresee all the situations that may arise, and if they did, could not practically set them all out. It is thus in the nature of our legal system that areas of uncertainty exist and that judges clarify and augment the law on a case-by-case basis." ${ }^{M \mathrm{k}}$

Faisal A. Bhabha, "Tracking 'Terrorists' or Solidifying Stereotypes? Canada's Anti-Terrorism Act in Light of the Charter's Equality Guarantee" (2003) 16 Windsor Rev. Legal Soc. Issues 95 at 125. Lome Sossin, "Developments in Administrative Law: The 2001-2002 Term" (2002) 18 Sup. Cl. L. Rev. (2d) 41 at 53.

Elmer A. Driedger, Consiruction of Statutes, 2d ed. (Toronto: Butterworths, 1983) at 87, cited in Bristol-Mycrs Squibb Co. v. Canada (Attorney General), [2005) I S.C.R. 533, 2005 SCC 26 at paras. 95-96 (noting that this "modern" nule prevails in the Supreme Courn's jurispnudence).

For an overview of these rules, see Ruth Sullivan, Staturon Imerpretation (Toronto: Irwin Law, 1997). One useful convention might be that of in pari materia: "Where statutes are closely related, a court may find it appropriate to rely on definitions or other interpretive provisions found in one statute to help interpret the other" (ibid. at 124). Note also s. 15 of the federal interpretation Act, R.S.C. 1985, c. I-21: "Where an enactment contains an interpretation section or provision, it shall be read and construed ... as being applicable to all other enactments relating to the same subject-matter unless a contrary intention appears." To the extent this convention is applied, the definition of "threats to the security of Canada" found in the CSIS ACt might be used to breathe meaning into other statutory invocations of at least this lerm, and perhaps also its variants. Suresh v. Canada (Minister of Cinizenship and Immigration), [2002] I S.C.R. 3, 2002 SCC 1 [Suresh]. See Camadian Foundation for Children, Youth and the Law v. Camada (Athorney General), [2004] 1 S.C.R. 76, 2004 SCC 4 at para. 15 ("A law is unconstitutionally vague if it "does not provide an adequate basis for legal debate' and 'analysis'; 'does not sufficiently delineate any area of risk'; or 'is not intelligible." The law must offer a 'grasp to the judiciary") [citations omitted]. 
At core, however, the fundamental pre-requisite to this sort of limiting interpretation is meaningful access to courts willing to probe carefully government claims of national security. The rules of statutory interpretation do not prescribe mechanical outcomes. Even in applying such doctrines to assign meaning to ambiguous terms, courts may extend deference to the initial interpretations offered by government officials. ${ }^{99}$ Under these circumstances, how assertive Canadian courts have been in evaluating the legitimacy of government national security actions is the key question.

\section{Judicial Treatment of National. SeCURity Provisions}

For constitutional reasons, any judicial scrutiny of national security issues likely comes in different forms, depending on the effect of the national security provision. Section 7 of the Charter constitutes a ground for judicial review where state action potentially deprives a person of life, liberty and security of the person without fundamental justice. Thus, state action imposing a limit on liberty ${ }^{100}$ or potentially inflicting physical or serious psychological injury $^{101}$ will trigger scrutiny under $\mathbf{s .} 7$.

On the other hand, a statute merely regulating parties, or having the sort of regulation-limiting or-expanding effects discussed in relation to information or privacy laws, will generally not attract such constitutional attention. Such statutes will be reviewable, therefore, on standard administrative law grounds, if at all.

In both cases, the court's response to a national security decision will likely be strongly influenced by its view of its proper role in relation to the government. Here, the question of curial deference to the executive branch will be squarely engaged.

These hypotheses are addressed in the section that follows, first in relation to straight administrative law, and then with reference to the constitutional notion of $\mathrm{s}$. 7 fundamental justice.

See Barrie Public Urilities v. Canadian Cable Television Assn., [2003] I S.C.R. 476, 2003 SCC 28 at para. I6; J.D. Irving. Ltd. v. International Longshoremen's Assn. Local 273, [2003] 4 F.C. 1080, 2003 FCA 266 at paras. $79-80$ (both cases noting that statutory interpretation is a pure question of law, a conclusion that feeds into the courn's "pragmatic and functional analysis" of how much administrative law deference to extend a govemment official and which counsels less deference, but which does not automatically prompt a court to be non-deferential).

Sec e.g. Gallont v. Canada (Depuly. Commissioner. Correctional Service Canada), [1989] 3 F.C. 329 at 337 (C.A.), Pratte J.A. ("it can no longer be doubted that the decision to transfer an inmate to a penal institution where his freedom will be more severely restricted is, in effect, a committal to a 'prison within a prison' which deprives the inmate of his liberty. Such a decision must therefore, according to $\mathrm{s} .7$ of the Churter be made 'in accordance with the principles of fundamental justice"').

Chaoulli v. Quebec (Antorney General), [2005] I S.C.R. 791, 2005 SCC 35 at para. 116 et seq., McLachlin C.J.C. (noting that "[s]erious psychological effects [as well as physical harm] may engage s. 7 protection for security of the person"). 


\section{A. Court SCRUtiny of National Security Decisions IN ADMINISTRATIVE LAW}

\section{General Pattern}

In the last several decades, Canadian administrative law has, on the whole, taken on a deferential hue when dealing with decisions made by members of the executive branch. Where the decision made by the administrative decision-maker is viewed as "discretionary," reviewing courts in Canada have traditionally been undemanding, intervening only in response to an "abuse of discretion." In practice, such an abuse was demonstrated by evidence of bad faith, reliance on improper purposes or considerations, or discrimination.

As the Supreme Court recently acknowledged in Baker v. Canada ${ }^{102}$ this approach sat uncomfortably with the Supreme Court's jurisprudence on deference in relation to so-called "errors of law" - errors made by decision-makers in interpreting statutes they are obliged to apply. With errors of law, for some time, the Supreme Court has extended deference (or not) depending on its assessment of a number of variables. These variables - components of what the Court has called the "pragmatic and functional test" - historically have been marshalled by the Court to decide whether the error of law is best viewed as a matter within the jurisdiction of the administrative decision-maker (in which case it will be disturbed only if "patently unreasonable") or a matter circumscribing the scope of the decision-maker's jurisdiction (in which case the court will intervene in response to any error). ${ }^{103}$

After Pushpanathan v. Canada, ${ }^{104}$ this traditional justification of locating the error as within or at the margins of the decision-maker's jurisdiction has eroded and the Court engages in the pragmatic and functional test simply to decide how much deference need be extended to a decision-maker making an alleged error of law. This deference is now measured on a three-point spectrum running from the zero deference standard of "correctness," through the intermediate deference "reasonableness simpliciter," to the maximum deference standard of "patently unreasonable."

In Baker, the Court acknowledged that the distinction between a decision that is discretionary - and thus traditionally reviewable on an abuse of discretion standard - or a decision of law - and thus reviewable on a standard determined by the pragmatic and

[1999] 2 S.C.R. 817 at para. 54 [Baker].

See e.g. U.E.S. Local 298 v. Bibeault. [1988] 2 S.C.R. 1048 ut para. 123 (setting out the purpose and content of the pragmatic and functional test); Canadian Broakcasting Corp. v. Canada (Labour Refutions Besard). [1995] I S.C.R. 157 at para. 30 (discussing the role of the pragmatic and functional test in "distinguishing jurisdictional questions from questions of law within a tribunal's jurisdiction"). [1998] I S.C.R. 982 at para. 28 (incorporating a three-spectrum standard of review into judicial review and noting that "it should be understood that a question which 'goes to jurisdiction' is simply ... an error on an issue with respect to which, according to the outcome of the pragmatic and functional analysis, the tribunal must make a correct interpretation and to which no deference will be shown"). 
functional test - is often impossible to make. ${ }^{105}$ Accordingly, in Baker, the Court extended the pragmatic and functional test to both discretionary decisions and decisions interpreting law.

Since one end of the spectrum produced by this test is no deference at all, Baker conceivably opened the door to more demanding review of those decisions once only assailable on the grounds of abuse of discretion. ${ }^{106}$ Yet, both in practicc and doctrinally, the Court has been unwilling to apply the non-deferential standard of "correctness" to discretionary decisions by at least ministerial-level decision-makers. ${ }^{107}$ Instead, it has often concluded that such decisions are entitled to a level of deference equivalent, if not identical, to that traditionally applied under the undemanding abuse of discretion approach. Namely, such decisions must typically be patently unreasonable, which in the Court's mind has often been conflated with the classic abuse of discretion requirements of bad faith, reliance on improper considerations or similar such flaws. ${ }^{108}$

Baker, supra note 102. See also Suresh, supra note 96 at paras. 35-36, noting that Baker confirmed that the pragmatic and functional approach should be applied to all types of administrative decisions in recognition of the fact that a uniform approach to the determination of the proper standard of review is preferable ... The Cour specified in Baker ... that a nuanced approach to determining the appropriate standard of review was necessary given the difficulty in rigidly classifying discretionary and non-discretionary decisions.

See e.g. Dr. Q. v. College of Physicians and Surgeons of British Columbia, [2003] I S.C.R. 226, 2003 SCC 19 at para. 24, citing Binnie J. in Mount Sinai Hospital Center v. Quebec (Minister of Health and Social Senvices), [2001] 2 S.C.R. 281, 2001 SCC 41 at para. 54 [Sinai], and noting that "under the pragmatic and functional approach, even 'the review for abuse of discretion may in principle range from correctness through unreasonableness to patent unreasonableness.' The nominate grounds [of abuse of discretion], language of jurisdiction, and ossified interpretations of statutory formulae, while still useful as familiar landmarks, no longer dictate the joumey." For a comprehensive discussion of the implications of Baker, see David Dyzenhaus, ed., The Unity of Public Law (Oxford: Hart Publishing, 2004) [Dyzenhaus, Unity].

See e.g. Baker, supra note 102 at para. 56 ("[i]ncorporating judicial review of decisions that involve considerable discretion into the pragmatic and functional analysis for errors of law should not be seen as reducing the level of deference given to decisions of a highly discretionary nature"): Sinai, ibid. at para. 58. Binnie J., concurring in the result ("[d]ecisions of Ministers of the Crown in the exercise of discretionary powers in the administrative context should generally receive the highest standard of deference, namely palent unreasonableness").

Suresh, supra note 96 at para. 29 ("the reviewing court should adopt a deferential approach to this question and should set aside the Minister's discretionary decision if it is patently unreasonable in the sense that it was made arbitrarily or in bad faith, it cannot be supponed on the evidence, or the Minister failed to consider the appropriate factors"); Ahani v. Canada (Minister of Citizenship and Immigration), [2002] I S.C.R. 72, 2002 SCC 2 at para. 16 [Ahani] (same): C.U.P.E. v. Ontario (Minister of Labour), [2003] I S.C.R. 539, 2003 SCC 29 at para. 176 [CUPE]:

In applying the patent unreasonableness test, we are not to reweigh the factors. But we are entitled to have regard to the importance of the factors that have been excluded altogether from consideration. Not every relevant factor excluded by the Minister from his consideration will be fatal under the patent unreasonableness standard. The problem here, as stated, is that the Minister expressly excluded factors that were not only relevant but went straight to the heart of the ... legislative scheme.

For a comprehensive discussion of Suresh and Baker and their impact on administrative law doctrines, see David W. Elliot, "Suresh and the Common Borders of Administrative Law: Time for the Tailor?" (2002) 65 Sask. L. Rev. 469. 


\section{THE QUESTION OF DEFERENCE IN NATIONAL SECURITY MATTERS}

In such an environment, courts asked to review the inherently discretionary national security determinations made by government will likely not intervene readily to disturb these decisions. Indeed, the U.K. House of Lords in United Kingdom (Secretary of State for the Home Department) v. Rehman ${ }^{109}$ illustrated recently that even courts unencumbered with the Supreme Court of Canada's complicated deference jurisprudence will extend deference on national security issues. There, the appellant was denied indefinite leave to remain in the U.K. by virtue of an affiliation with a group defined by the U.K. government as a terrorist organization. The decision was rendered pursuant to a provision in U.K. law authorizing such a decision, and a subsequent deportation, "in the interests of national security." At issue by the time the matter reached the House of Lords was the meaning of this phrase.

In their speeches, their Lordships were not prepared to grant the government a carte blanche in its assessment of national security. Lord Slynn of Hadley wrote, for example, that under the relevant statute, '“the interests of national security' cannot be used to justify any reason the Secretary of State has for wishing to deport an individual from the United Kingdom. There must be some possibility of risk or danger to the security or well-being of the nation which the Secretary of State considers makes it desirable for the public good that the individual should be deported."110

However, at least one Law Lord was quick to point out that the question of whether a threat to national security existed or not was best left in the hands of the government. Thus, Hoffman L.J., in his speech, urged that "decisions as to whether something is or is not in the interests of national security are not a matter for judicial decision. They are entrusted to the executive." "In a remarkable postscript worthy of citation in full, Hoffman L.J. added:

I wrote this speech some three months before the recent events in New York and Washington. They are a reminder that in matters of national security, the cost of failure can be high. This seems to me to underline the need for the judicial arm of govemment to respect the decisions of ministers of the Crown on the question of whether support for terrorist activities in a foreign country constitutes a threat to national security. It is not only that the executive has access to special information and expertise in these matters. It is also that such decisions, with scrious potential results for the community, require a legitimacy which can be conferred only by entrusting them to persons responsible to the community through the democratic process. If the people are to accept the consequences of such decisions, they must be made by persons whom the people have elected and whom they can remove. 112

While the Canadian case law is not quite as blunt as Hoffman L.J.'s speech, the highly deferential attitude demonstrated by Rehman also animates the Canadian jurisprudence.

(2001), 281 N.R. 125, 2001 UKHL 47 [Rehman]. United Kingdom courts have traditionally not employed a spectrum of review standards or a pragmatic and functional Iest, instead relying on a concept of "reasonableness" in reviewing diseretionary administrative decision making. As Rehman illustrales, deference has recently become an important consideration in select cases, involving such things as forcign affairs and immigration. See discussion in Sir William Wade \& Christopher Forsyth, Administrative Law, 9th ed. (Oxford: Oxford University Press, 2004) at 351 ef seq. and 369. 
Indeed, in the leading case on point, Suresh, the Supreme Court of Canada cited with approval Hoffman L.J.'s deference-championing position in Rehman.

In Suresh, the Supreme Court of Canada reviewed the Minister of Citizenship and Immigration's "discretionary" determination that a refugee, Mr. Suresh, constituted a "danger to the security of Canada" as that phrase was used in the then-Immigration Act. Applying its standard "pragmatic and functional" test to determine the deference to be accorded the Minister, the Court concluded that the Minister's decision would be disturbed only in egregious circumstances. In partial support of this conclusion, the Court noted that it was the Minister making the determination. It then cited Hoffman L.J.'s Rehman observations that the Minister "has access to special information and expertise in ... matters [of national security]."

This fact - read together with the limited appeal mechanism in the $A c t$, the difficult balancing of the competing humanitarian purposes of the $A c t$ and the extremely fact-intensive and contextual nature of the national security determination - prompted the Court to apply a standard of "patently unreasonable." A "patently unreasonable" decision, in the Court's mind, was one "made arbitrarily or in bad faith, [that] cannot be supported on the evidence, or [where] the Minister failed to consider the appropriate factors." 14

While Suresh dealt explicitly with "danger to the security of Canada" determinations under the now-replaced Immigration Act, its holding will likely inform judicial reviews of national security findings under other federal statutes. ${ }^{115}$ It seems very possible that the same factors motivating deference in Suresh would also be present in many other national security related cases. Appeal rights from national security determinations are uncommon. These statutes - whether they have an explicit national security focus or a broader ambit - will likely require the balancing of competing objectives. Any national security determination will be fact-intensive and highly contextual. Finally, the decision-maker may well have access to special information and expertise.

Suresh, in other words, can be read as signalling a limited role for the courts in policing the exercise of executive branch discretion on national security matters, even outside the immigration context. Review is not barred, but successful review will require a government decision that is patently unreasonable or, as that term is sometimes defined, clearly irrational. ${ }^{116}$ This is not, in other words, that tantalizing circumstance hinted at (but actively discouraged) by the post-Baker approach: review of a discretionary decision on the

Suresh, supra nolc 96 at paras. $31,33$.

It J Jid. at para. 29. See also Ahami, supra note 108 at para. 16 ("'the standard of review on the [danger to the security of Canada] decision is whether the decision is patently unreasonable in the sense that it was made arbitrarily or in bad faith, cannot be supported on the evidenct, or did not take into account the appropriate factors. A reviewing court should not reweigh the factors or interlere merely because it would have come to a different conclusion").

Is Sec, e.g. Almrei v. Camada (Mfinister of Citizenship and Immigrotion), [2004] F.C.J. No. 509, 2004 FC 420 at para. IOI (QL) [Almrei \#1]: "While Suresh was written in the conlext ol deportation proceedings of a Convention refugee, its observations with respect to what constitutes a 'danger to the security of' Canada' are, in my view, applicable to detention review procedings pursuant to subsection $84(2)$ of the IRPA." 
least-deferential correctness standard of review. Commenting on Suresh, and its relationship to Baker, David Dyzenhaus has urged that Suresh signals a veritable rush by the Court to a patently unreasonable standard where discretionary decisions are being reviewed. ${ }^{17}$ Sossin echoes this view, suggesting that, at least in national security matters, "patent unreasonableness is the 'default' standard of review where the exercise of ministerial discretion is challenged." 18 For his part, David Mullan calls Suresh's reasoning a "perversion of the whole thrust of Baker and its willingness to allow for unreasonableness as opposed to patent unreasonableness review of a broad ministerial discretion in a case involving highly valued individual interests."119

Under these circumstances, legitimate questions arise as to how aggressive court review will be in reining in use of the inherently ambiguous, usually undefined concept of national security.

\section{IMPLICATIONS OF DEFERENCE}

The conclusions on deference set out above must be tempered by several caveats.

\section{a. Deference in Practice}

First, recent developments under the new Immigration and Refugee Protection Act suggest that deference does not necessarily leave government unencumbered with judicial oversight. The IRPA permits a person "inadmissible on grounds of security" to be deported, even where they are at risk of torture, if "in the opinion of the Minister, the person should not be allowed to remain in Canada on the basis of ... danger to the security of Canada." 120 In at least three cases to date in which the government has attempted to remove people under this provision, the Federal Court followed Suresh's approach to the national security assessment by pointing to the fact-intensive nature of the government's decision and holding that the appropriate standard of review was the deferential "patently unreasonable." 121 Nevertheless, in each case, the court returned the matter to the government for re-determination, urging that the government's conclusion was based on failure to consider proper factors or was not supported on the evidence before the decision-maker. ${ }^{122}$

A fourth case, focused on a government decision to deny a foreign national a stay of removal on the basis of a "pre-removal risk assessment," maintains this pattern. The IRPA permits a stay to be refused where the applicant constitutes a sufficient danger "to the

David Dyzenhaus, “Constituting the Rule of Law: Fundamental Values in Administrative Law" (2002) 27 Queen's L.J. 445 at 506.

Sossin, supra note 93 at 59 .

David Mullan, "Deference from Baker to Suresh and Beyond - Interpreting the Conflicting Signals" in Dyzenhaus, Unity, supra note 106, 21 at 60.

IRPA, supra note 40, s. 115.

Almrei v. Canada (Minister of Cirizenship and Immigration), [2005] F.C.J. No. 437, 2005 FC 355 at para. 32 (QL) [Almrei \#2]; Mahjoub v. Minister of Cihizenship and Immigration, [2005] F.C.J. No. 173, 2005 FC 156 at para. 42 (QL) [Mahjoub]; Sogi v. Canada (Minister of Citizenship and Immigration), [2005] 3 F.C. 517, 2004 FC 853 [Sogi \#1] (this case does not expressly identify s. 115, but conecrned a deportation order that must have been made after consideration of this section).

Almrei $\# 2$, ibid. at para. 95; Mahjoub, ibid. at para. 47 et seq.: Sogi $\$ 1$, ibid. at para. 18 et seq. 
security of Canada." 123 In Jaballah, the Federal Court rejected the government's decision to deny a stay, concluding that "the ultimate decision to refuse the application for protection was patently unreasonable based upon a finding of facts made without appropriate regard to all of the evidence and circumstances of the case." 124

While the court's holding referenced the patently unreasonable standard, it also arguably held open the door to an even more demanding standard: "Much of the argument of the applicant concerns alleged errors of law made in reaching the conclusions ... To the extent those have significance the standard of review is correctness." 125 This observation was not supported by a pragmatic and functional analysis, and no effort was made to reconcile this view with that expressed in Suresh. Whether it will influence further decisions by the Federal Court in IRPA matters remains unclear. It seems likely, however, that the Supreme Court's pragmatic and functional approach has closed the door to a court simply announcing that a given decision constitutes an error of law to which the correctness standard applies. ${ }^{126}$

\section{b. Common Law Procedural Faimess}

Second, the Supreme Court has persistently refused to extend deference to decision making processes that violate doctrines of common law procedural fairness, in other words processes that sit poorly with the court's concepts of due process. ${ }^{127}$

There is some evidence that even in relation to national security matters, unfair (and non-statutorily mandatory) procedures followed by the government may trigger demanding court review. Thus, in Zarrin v. Canada (Minister of Citizenship and Immigration), ${ }^{128}$ the applicant was denied admission to Canada pursuant to para. 19(1)(f)(iii)(B) of the then-Immigration Act. This provision allowed denial of entry to persons where there are "reasonable grounds to believe ... are or were members of an organization that there are reasonable grounds to believe is or was engaged in ... terrorism." On the facts, the material supplied to the court on judicial review by the relevant immigration officer disclosed "no evidence, documentary or otherwise, concerning the [alleged terrorist group] KDP's current

Ibid. at para. 32.

Sec e.g. Voice Construction Ltd. v. Construction \& General Workers" Union, Local 92, [2004] I S.C.R. 609. 2004 SCC 23 at paras. 19.21-22 (holding that "[0]nly after the standard of review is determined can the administralive tribunal's decision be scrutinized," that in examining a decision-maker's reasons prior to establishing the standard of review, "the car was put before the horse" by the lower courts, and that the standard of review is determined via "the analysis mandated by the pragmatic and functional approach").

CUPE, supra nole 108 at para. 100 ("It is for the courts, not the Minister, to provide the legal answer to procedural fairness questions. It is only the ultimate exercisc of the Minister's discretionary ... power ... that is subject to the 'pragmatic and functional' analysis, intended to assess the degrec of deference intended by the legislature to be paid by the courts to the statutory decision maker, which is what we call the "standard of review" "): Morean-Bernbe v. New Brunswick (fucticial Council), [2002] I S.C.R. 249, 2002 SCC 11 at para. 74 (procedural fairness requires "no assessment of the appropriate standard of judicial review. Evaluating whether procedural faimess, or the duty of fairness, has been adhered to by a tribunal requires an assessment of the procedures and safeguards required in a particular situation"). 
or past activities, formation or history." 29 Responding to this lack of evidence, the Federal Court concluded that:

[I]n order for the officer in this case to have made her determination that there were "reasonable grounds" to believe that the KDP was a terrorist organization, which was a central part of the subsection $I 9(1)(f)(i i i)(B)$ decision, such cvidence must have been considered by the officer, however, no such evidence was disclosed to the applicant. The applicant had no opportunity to review and respond to such evidence. and therefore, he was denied procedural faimess. ${ }^{130}$

Zarrin may represent an outlier case in the sense that had there been evidence supporting the immigration officer's conclusion, this evidence could probably have been exempted from disclosure under other statutory provisions. ${ }^{131}$ However, Zarrin does suggest that absent invocation of such a statutory provision, a violation of procedural fairness in a national security context may be vulnerable to judicial intervention, with no issue of deference arising. Whether this common law tendency will persist remains uncertain, given the willingness of courts to temper constitutionally-based due process protections in the name of national security. This latter issue is addressed below, in the section on Charter s. 7.

\section{c. Competing Statutory Considerations}

The emphasis on deference may also be tempered in certain limited circumstance where the statutory framework itself enhances the reviewing authority of the courts.

(i) Standard of Review Where the Statute Accords the Court a Special Role

Some statutes accord certain judges of the Federal Court a special role in reviewing national security decisions by the government. Key among these are the IRPA and the Canada Evidence Act.

\section{(l) Designated Judges Under the IRPA}

Section 76 of the IRPA anticipates a certain subset of Federal Court judges being "designated" to review security intelligence information and government security certificate and detention decisions under the Act. As the Federal Court noted in Sogi v. Canada (Minister of Citizenship and Immigration), ${ }^{132}$ by virtue of this status, "it is anticipated that a designated judge of the Court will have developed expertise in dealing with such [security] matters." On the specifics of that case, the Federal Court of Appeal has affirmed this view: "Federal Court judges are experts in assessing the advisability of disclosing security intelligence information.... [I]n a number of legislative contexts, Parliament considers

129

130

31 See, e.g. s. 86(1) of the present IRPA, supra note 40, specifying that "[t]he Minister may, during an admissibility hearing, a detention review or an appeal before the Immigration Appeal Division, make an application for non-disclosure of information." Notably, common law procedural faimess may be abrogated by statutes. See e.g. Knight v. Indian Head School Division No. 19, [1990] I S.C.R. 653 (holding that procedural fairness may be abrogated by statute, either through express language or necessary implication). 
Federal Court judges best-suited to determine the appropriateness of disclosing information that could be injurious to national security."133

In Sogi, at issue was whether an immigration adjudicator erred in refusing to release information to the applicant during a deportation proceeding. The adjudicator's refusal was made pursuant to s. 86(1) of the $I R P A$, allowing the Minister to seek non-disclosure of security-related information. In reviewing the adjudicator's decision, the court held that a judge would not be properly discharging his or her responsibilities "under the Act by approving, without question, a recommended arrangement for non-disclosure." ${ }^{134}$

Instead, in applying the pragmatic and functional test, the court concluded that it need not show any deference to an immigration adjudicator's decision not to release information on security grounds in a deportation proceeding under the IRPA. The designated judge has, as the Federal Court put it, "comparative expertise" to the adjudicator in assessing security intelligence. ${ }^{135}$ This consideration, coupled with other attributes of the pragmatic and functional test suggesting minimal deference, prompted the court to review the matter on a standard of correctness, a decision later affirmed by the Court of Appeal. ${ }^{136}$

Sogi may constitute a modest push-back by courts on deference in national security matters. Where national security conclusions are reached by non-national security specialists, and then scrutinized by specialized Federal Court judges growing increasingly comfortable reviewing intelligence information, the result of the pragmatic and functional test may point to little or no deference. It remains to be seen whether the Federal Court will extend this approach to non-IRPA contexts and engage in more demanding review of other national security statutory provisions; specifically, those capable of invocation by a wide cast of non-national security specialists. This list might include, for instance, information decisions made by the Commissioner of Official Languages or a Customs Officer under their respective statutes.

It is important, however, not to overstate the possibility of searching "designated" Federal Court judge review even under the IRPA itself. Suresh clearly teaches that where the decision-maker is the Minister equipped with full access to the intelligence apparatus of the state, courts should generally defer to that expertise. Perhaps reflecting its own "generalist" court discomfort with the subject, the Supreme Court did not carve out an exception for those circumstances in which the reviewing judge is himself or herself an expert in national security matters.

Perhaps for this reason, even "designated" Federal Court judges have applied varying and somewhat perplexing degrees of deference in their statutory review of ministerial-level national security decisions under $I R P A$. Proving this point requires a brief review of the complicated IRPA national security-motivated detention provisions. 
Under the $I R P A$, the Ministers of Immigration and Public Safety may sign a certificate declaring a foreign national or permanent resident inadmissible to Canada on grounds of security. ${ }^{137}$ Subsequently, a permanent resident may be held in detention, where the Ministers have reasonable grounds to believe the person to be a danger to national security. ${ }^{138}$ Foreign nationals meanwhile must be detained once a certificate is issued. ${ }^{139}$

Under $\mathrm{s} .80$ of the $A c t$, a Federal Court judge assesses the reasonableness of the Minister's certificate. ${ }^{140}$ A judge may quash the certificate only where he or she views it as unreasonable. ${ }^{141}$ Thus, judges employ an inherently deferential standard in reviewing a ministerial certificate. Moreover, the judge must hear evidence on this matter in camera and on an ex parte basis when the government so requests, if the judge considers that disclosure of the information would be harmful to national security. ${ }^{142}$

Subsequently, with respect to a foreign national, the judge may order the foreign national's release from detention under terms and conditions that the judge considers appropriate. This power arises if a person has not been removed within 120 days of the Ministers' certificate being found reasonable. Section 84 requires, however, that prior to ordering this release the judge must be "satisfied that," inter alia, "the release will not pose a danger to national security or to the safety of any person."1+3

This expression "satisfied" implies a more testing standard of review than the $\mathbf{s .} 80$ reference to "reasonableness," one that more closely implicates the court in reviewing the merits of the security intelligence. At least one judge seems to have come to this conclusion. As the Federal Court put it in Jaballah v. Canada (Minister of Citizenship and Immigration), ${ }^{144}$ " $t$ the conclusion [on whether the foreign national will not pose a danger to national security if released] is one 1 must make, not one for the [Canadian Security and Intelligence] Service, or not one certified by the Ministers here."14s

Meanwhile, s. 83 governs the continued detention of a permanent resident (as opposed to a foreign national). It requires a judge to order that a detention of a permanent resident be continued if "satisfied" that the permanent resident, inter alia, continues to be a danger to national security. Certainly, much like $\mathrm{s}$. 84 , this provision appears to ask courts to determine for themselves whether the person constitutes a national security threat. However, Federal Court judges appear not to have harmonized their ss. 83 and 84 approaches. Specifically, in Re Charkaoui, the court described its s. 83 role as simply to re-apply the test of "reasonableness" used to assess whether the ministerial detention warrant (for the permanent

IRPA, supra note 40, s. 77.

Ibid., s. 82.

Jbid., s. 82(2). A "foreign national" is defined as a person who is not a Canadian citizen or permanent resident. Jbid., s. 2.

Jbid., s. 80.

Jbid., s. 80(2).

Jbid., s. 78.

Ibid., s. 84 [emphasis addled].

(2004), 247 F.T.R. 68, 2004 FC 299, McKay J. [Jaballah \#1].

lbid. at para. 44 , in relation to review of a detention under s. 84(2). 
resident) was properly issued, despite the admonishment in the $A C t$ that the court be "satisfied" of the threat. ${ }^{146}$

In a subsequent Charkaoui detention review, ${ }^{157}$ the Federal Court reiterated this view, urging that because the ministers make their initial detention decision on the basis of "reasonable grounds to believe" that the person is a security threat, "[i]t is logical to assume that in subsequent reviews by a designated judge, the same standard will be used."188 In applying this standard, however, the judge incorporated an element of dynamism: the factual circumstances change with the passage of time, influencing the outcome of the "reasonable grounds" inquiry. In Charkaoui, the prolonged period of detention, coupled with the notoriety of the case, "neutralized" the security threat, prompting the judge to order Mr. Charkaoui's release on conditions, pending the outcome of deportation proceedings.

All told, the $I R P A$ jurisprudence to date suggests similar statutory provisions implying a probing standard of review of national security decisions - that a judge be "satisfied" may generate more court deference to the government in one context than in another, for reasons that are not apparent. As Charkaoui suggests, deference does not always mean the government prevails. It does, however, presumably case the government's case.

The one assertive quality to the standard of review proposed in Charkaoui concerns the Court's response to the in camera and ex parte nature of the proceedings. In these circumstances, held the Court, judges should take on a pseudo-inquisitorial role, in which the designated judge "must be curious, concerned by what is advanced, and maintain a skeptical attitude with the objective of conducting a critical review of the facts.... In a word, the designated judge must seriously test the protected documentation and information."1+9

\section{(3) Designated Judges Under the Canada Evidence Act}

Like the Immigration and Refugee Protection Act, the Canada Evidence Act creates "designated judges" 150 hearing cases on an in camera and ex parte basis. ${ }^{151}$ While there are few cases under the newly revised Canada Evidence Act, Federal Courts may be moderately probing in reviewing government efforts to bar disclosure of alleged, national security-related material under the $A c t$, although perhaps to no good effect.

Demonstrating this point requires an overview of the Canada Evidence Act process. Under the Act, participants in a civil or criminal proceeding must notify the federal Attorney General as to whether they intend (or believe another participant or person intends) to disclose national security information. The Attorney General may then authorize disclosure, or alternatively may deny this authorization, in which case the matter is taken up by the Federal Court. Under s. 38.06, there are two possible inquiries: first, the court authorizes

[2004] I F.C. 528, 2003 FC 882 at paras. 36-37 [Charkoonj \#1], aff d [2004] I F.C. 451,2003 FCA 407 [Charkaoui C.A.\#I].

Re Charkaoui, [2005] 3 F.C. 389, 2005 FC. 248 [Charkaowi \#2].

Ibid. at para. 30.

Charkaoui \#1, supra note 146 at para. 44.

Canada Evidence Act, supra note 59 , s. 38.

See ibid., s. 38.11, requiring in camera proceedings and permitting ex parte representations by the govemment. 
disclosure unless persuaded that disclosure would be injurious to national security. Second, even where disclosure would be injurious, the information may still be released if the public interest in disclosure exceeds the injury. ${ }^{152}$

Courts clearly have an important role to play under this test. As the Federal Court has indicated, "Parliament has required the designated judge to balance competing interests, not simply to protect the important and legitimate interests of the state."153 The Court has also held that under s. 38 of the $A c t$, "the designated judge has a very broad discretion to exercise." 154 Still, when it comes to weighing whether disclosure would in fact be injurious, the Federal Court of Appeal has concluded that deference is owed the Minister:

[T] he Attorney General's submissions regarding his assessment of the injury to national security, national defence or international relations, because of his access to special information and expertise, should be given considerable weight by the judge... The Attomey General assumes a protective role vis-à-vis the security and safety of the public. If his assessment of the injury is reasonable. the judge should accept it. ${ }^{\text {is }}$

Further, the Canada Evidence ACt allows the government to short-circuit testing court review. Thus, the $\mathrm{ACt}$ empowers the Attomey General to personally issue a certificate on national security grounds. ${ }^{156}$ Issuance of the certificate has the effect of barring the disclosure of the information in a proceeding. In other words, the certificate may trump an order from the Federal Court authorizing disclosure under s. 38.06.

Review of this certificate decision is perfunctory. The Minister's decision may be challenged before a single judge of the Federal Court of Appeal. The role of this judge is simply to determine whether the information covered by the certificate does relate to national security, in which case the judge must confirm the certificate. ${ }^{157}$ Thus, the judge's role is simply to determine whether the Minister pigeon-holed the information correctly, not to weigh the competing interests of disclosure and non-disclosure.

No decisions have been issued under this latter provision. It therefore remains to be seen if a Federal Court of Appeal judge will be prepared to reach beyond this limited statutory appeal power and invoke an inherent power to review the Minister's exercise of discretion in issuing the certificate. ${ }^{138}$

152 Ibid, s. 38.06

153 Canada (Attorney General) v. Ribic (2001), 22I F.T.R. 310, 2002 FCT 839 at para. 22 [Ribic \#2].

154 Ribic v. Canada (2002), 112 A.C.W.S. (3d) 1080, 2002 FCT 290 at para. 2 [Ribic \#I].

iss Canada v. Ribic, [2005] I F.C. 33, 2003 FCA 246 at para. 19 [Ribic C.A.].

156 Canada Evidence Act, supra note 59, s. 38.13.

157 lbid., s. 38.131.

138 By way of analogy, see Babcock v. Canada (Altorney General), [2002] 3 S.C.R. 3, 2002 SCC 57 at paras. 22, 25, 39 (involving judicial ruview of a roughly analogous certification of a cabinct "confidence" under s. 39 of the Canada Evidence Act, in which the Court held that if "it can be shown from the evidence or the circumslances that the power of certification was exercised for purposes outside those contemplated by s. 39, the certification may be set aside as an unauthorized exercise of executive power." A certificate may, in other words, be challenged on judicial review, not on its merits, but on the basis that the information "does not on its face fall within s. 39(1), or where it can be shown that the Clerk or minister has improperly exercised the discretion conferred by s. 39(1)"). 
(ii) Conclusion

In sum, these discussions of the IRPA and the Canada Evidence Act suggest that where the courts find a statutory "hook" by which to scrutinize government national security claims, they may engage in a more demanding review than might be counselled by Suresh. Even then, however, the IRPA detention jurisprudence - and language from the Federal Court of Appeal in the Canada Evidence Act context - suggests that courts relying on statutory language seemingly permitting active court review will manifest different and unpredictable amounts of deference.

Absent a definite statutory standard of review, only in the rarest of circumstances can judicial review be described as searching or based on a correctness standard. These unusual scenarios include a violation of procedural fairness (not mandated by a statute) or where non-security experts render a national security decision reviewed before an expert Federal Court judge. The recent Jaballah case hints at correctness review where the court assesses whether a decision-maker erred in law in making a decision under certain other IRPA provisions, but this position - taken without reference to the pragmatic and functional test - may prove unsustainable.

What this section also makes clear is that this review, deferential or not, is often conducted in unusual circumstances; specifically, in camera and on an ex parte basis.

\section{B. COURT SCRUTINy Where Fundamental Justice IS at ISSUE}

Judicial review pursuant to $s .7$ of the Charter stands as a further, but only mild, footnote to the general, Suresh-like deferential orientation of courts in national security determinations. As noted, s. 7 of the Charter provides that no individual may be deprived of life, liberty or security of the person absent fundamental justice. Its most critical component, therefore, is a procedural — and, less commonly, substantive — entitlement to "fundamental justice" prior to any deprivation of the $s .7$ enumerated rights.

\section{Substantive Guarantees}

The Supreme Court has employed the substantive aspect of fundamental justice to signal some constraints on government invocations of national security. Thus, in Suresh itself, the Supreme Court applied the substantive aspects of s. 7 to the phrase "danger to the security of Canada" in the Immigration $\mathrm{Act}$, as it then was. On the facts, Mr. Suresh faced the prospect of torture if deported to Sri Lanka. Under such circumstances, his Charter s. 7 interests were clearly implicated.

The engagement of s. 7 had two consequences for Mr. Suresh's case. First, because Mr. Suresh's claim triggered application of s. 7, the Supreme Court expended some effort disceming whether, as a substantive matter, fundamental justice would preclude deportation to torture. Concluding that in most instances it would, the Court held that "insofar as the Immigration ACl leaves open the possibility of deportation to torture, the Minister should 
generally decline to deport refugees where on the evidence there is a substantial risk of torture."159

Second, and more importantly for this article, the triggering of $\mathrm{s.} 7$ raised a question of whether the very expression "danger to the security of Canada" violated fundamental justice. In this last regard, the Court was asked to consider whether the expression "danger to the security of Canada" violated $s .7$ by virtue of being unconstitutionally vague. The doctrine of unconstitutional vagueness, noted the Court, may render a statutory provision unconstitutional either "(1) because it fails to give those who might come within the ambit of the provision fair notice of the consequences of their conduct; or (2) because it fails to adequately limit law enforcement discretion."160

In ultimately concluding that the phrase was not impermissibly vague, the Court acknowledged that the term "danger to the security of Canada" is difficult to define and "is highly fact-based and political in a general sense."161 For these reasons, the Court accepted that "danger to the security of Canada" should be given "a fair, large and liberal interpretation in accordance with international norms." 162 The term does not, however, permit open-ended government discretion. As the Court put it, the security danger finding "nevertheless demands proof of a potentially serious threat." ${ }^{63}$ The Court summed up its view as follows:

These considerations lead us to conclude that a person constitules a "danger to the security of Canada" if he or she poses a serious threat to the security of Canada, whether dinect or indirect, and bearing in mind the fact that the security of one country is often dependent on the security of other nations. The threat must be "serious", in the sense that it must be grounded on objectively reasonable suspicion based on evidence and in the sense that the threatened harm must be substantial rather than negligible. ${ }^{16-1}$

Defined this way, the phrase was not unconstitutionally vague. ${ }^{165}$

Thus, to be constitutional, the phrase "danger to the security of Canada" in the then-Immigration $\mathrm{Act}$ had to be read as requiring the government to adduce evidence producing an objectively reasonable suspicion of a serious threat of substantial harm. Interpreted in this manner, a government decision failing to meet this standard would presumably also now fail to meet the requirements of the statute, as "read-in" by the Supreme Court. The decision-maker, in such circumstances, would be exceeding its jurisdiction, giving rise to a plain vanilla administrative law complaint. As a consequence, the Supreme Court's constitutional reasoning provides greater certainty to its administrative law position, establishing some additional guidelines on exactly what sort of government decision might prompt successful court review. 
While the Court was interpreting a specific phrase in the Immigration Act - "danger to the security of Canada" - it seems reasonable to presume that its conclusions will colour the approach courts take to other legislative invocations of national security. ${ }^{166}$ Caution is warranted, however, in reading too much administrative law significance into this constitutional discussion. Since the constraints "read-in" to the phrase "danger to the security of Canada" were prompted by the Supreme Court's efforts to interpret the phrase in a fashion consistent with fundamental justice, there is no solid legal reason to assume that this same definition must apply to other national security provisions in other statutes that do not trigger s. 7, that is, do not impinge on someone's life, liberty or security of the person.

\section{Procedural Guarantees}

In comparison, $\mathrm{s}$. 7's guarantee of procedural due process has had limited impact on the conduct of national security-related judicial review. In Suresh, the Supreme Court ultimately allowed Mr. Suresh's appeal with reference to the procedural guarantees contained in s. 7. Specifically, it held that, confronted with the prospect of being deported to torture, $\mathrm{Mr}$. Suresh "must be informed of the case to be met" and that an "opportunity be provided to respond to the case presented to the Minister," including through the presentation of evidence countering the view that he constituted a national security threat. ${ }^{167}$ However, information provided by the government to inform Suresh of the case against him was legitimately "[s]ubject to privilege or similar valid reasons for reduced disclosure, such as safeguarding confidential public security documents." 168 Further, the Court emphasized that "the Minister must be allowed considerable discretion in evaluating future risk and security concerns. This factor also suggests a degree of deference to the Minister's choice of procedures since Parliament has signaled the difficulty of the decision by leaving to the Minister the choice of how best to make it." 169 National security, in other words, tempers the sort of procedures courts will insist upon as part of constitutional fundamental justice, even outside any s. 1 analysis. ${ }^{170}$

In practice, and as Suresh suggests, the courts have consistently refused to employ the procedural component of fundamental justice to limit government recourse to in camera and ex parte proceedings or to compel full disclosure of government national security information. For instance, in Canada (Minister of Employment and Immigration) $v$. Chiarelli, ${ }^{171}$ the respondent was ordered deported from Canada after the Security Intelligence Review Committee (SIRC) created under the CSIS ACr determined that the respondent was likely to engage in organized crime. The respondent was given only limited access to evidence adduced at the SIRC hearing, pursuant to the then-existing rules under the Immigration Act and the CSIS ACt. The respondent challenged the constitutionality of this procedure. The Supreme Court of Canada held that while the individual has a strong interest

See e.g. Re Charkaous. [2004] F.C. 32, 2003 FC 1419 at para. 159 [Charkooui \#3], aff d [2005] 2 F.C. 299, 2004 FCA 421 [Charkaoui C.A. \#2] where the Federal Court ciles the Surresh decision in support of its conclusion that "danger to the security of Canada" under the $I R T^{2} A$ detention system is not unconstitutionally vague.

Ibid.

Ibid. at para. 120.

For a critique of this approach, see Mullan, supra note 119 at 47.

[1992] I S.C.R. 711 [Chiarelli]. 
in a fair procedure in SIRC hearings, "the state also has a considerable interest in effectively conducting national security and criminal intelligence investigations and in protecting police sources." 172 The Court cited with approval a U.K. House of Lords decision, R. v. Secretary of State for the Home Department, ex parte Hosenball, ${ }^{173}$ in which Denning L.J. observed that "[t]he public interest in the security of the realm is so great that the sources of information must not be disclosed, nor should the nature of the information itself be disclosed, if there is any risk that it would lead to the sources being discovered." In the result, the Supreme Court in Chiarelli concluded that fundamental justice did not require that the respondent be given access to "criminal intelligence investigation techniques or police sources used to acquire that information."174

Similarly, in Ruby v. Canada, ${ }^{175}$ at issue was whether criminal defence lawyer Clayton Ruby was entitled to access information that may or may not have been collected on him by CSIS. The government claimed that any such information was exempted by the "national security" exemption contained in s. 21 of the Privacy Act. Mr. Ruby challenged this decision, in part by bringing a constitutional challenge to the ex parte and in camera features of the judicial review procedure under the $A c t$. Specifically, the appellant argued that these procedures were contrary to Charter s. 7 fundamental justice procedural protections.

Without deciding whether 5.7 was triggered by a violation of privacy, the Supreme Court of Canada rejected Mr. Ruby's claim, holding that fundamental justice was not violated. The procedure complained of did not, in the Court's view, "fall below the level of fairness required by s. 7." ${ }^{136}$ In supporting its conclusion, the Court noted that even the appellant had agreed that "the state's legitimate interest in protection of information which, if released, would significantly injure national security is a pressing and substantial concern."177 This consideration clearly led the Court to temper its expectations as to the procedure guaranteed by $5.7 .^{178}$

The Federal Court took a similar balancing approach in a recent challenge to the constitutionality of the national security procedures of the Immigration and Refugee Protection Act. In Charkaoui, ${ }^{179}$ the applicant urged that fundamental justice was violated by the process set out in the IRPA for assessing the reasonableness of a security certificate and the continued detention of a permanent resident. Specific objections were made to the role of the designated judge in the process, the non-disclosure of national security-related

Jbid. at 744.

[1977] 3 All E.R. 452 (C.A.) at 460.

Chiarelli, supra note 171 at 746.

Ruby, supra note 56.

Ibid. at para. 51 .

Ibid. at para. 43.

For a recent case in which an in camera proceeding was challenged on a series of constitutional grounds, see Re Vancowver Sum, [2004] 2 S.C.R. 332, 2004 SCC 43 at para. 52 (holding, in a case concerning the constitutionality of $s .83 .28$ of the Criminal Code - an anti-terrorism provision allowing judicial investigatory hearings - that "[i]n the course of a public hearing a judge may order that part of the proceedings be held in camera, thus excluding the public for from that part of the hearing. I3ut, of course, in such a case, the fact that an in camera hearing is taking place, as well as the overall context in which it was ordered, are in the public domain, subject to challenge, inter alia by the press and to comments by interested parties and by the public").

Charknoui \#3, supra note 166 at para. 73. 
information, the in camera hearings held in the absence of the person concerned and his counsel and the standards of "reasonableness" employed in reviewing the Minister's decision.

Prior to addressing the $\mathrm{s.} 7$ issue raised by the applicant, the Federal Court observed that national security decisions involved a complicated balancing act. On the one hand, " $[w] e$ live in an era when threats to our democracy frequently come from unconventional acts that cannot be detected by unsophisticated investigations or traditional means. The methods used to obtain protected information must not be revealed." ${ }^{80}$ On the other hand, "the right of a permanent resident to be informed of the circumstances giving rise to the certificate issued against him is a fundamental right."181

In the court's view, the $A c t$ strives to balance these competing concerns ${ }^{182}$ by "tak [ing] the existence of opposing interests into consideration and strik[ing] an acceptable balance between those interests. The fact that a designated judge is involved in striking this balance adds credibility to the procedure and ensures objectivity in achieving the result." ${ }^{183}$ In a conclusion affirmed by the Federal Court of Appeal, the Court rejected the applicant's argument that Charter s. 7 was violated, that the IRPA process imperiled judicial independence or that, because of the in camera and ex parte nature of much of the proceedings, the judge was partial. ${ }^{\text {ISt }}$

The Federal Court of Appeal, in the same case, rejected Mr. Charkaoui's argument that s. 7 obliged the creation of a special security-cleared amicus curiae entitled to review the full evidence and replicate an adversarial hearing before the judge. This idea has been part of public discourse since at least March 2002, when Federal Court Justice Hugessen publicly complained at an academic event that the IRPA security certificate procedures make judges "a little bit like a fig leaf." He proposed "some sort of system somewhat like the public defender system where some lawyers were mandated to have full access to the CSIS files, the underlying files, and to present whatever case they could against the granting of the relief

Ibid. at para. 98.

thid. at para. 104.

Ibid. at para. 121. Mr. Charkaoui also argued that the IRPA provisions violated a number of other constitutional principles, beyond s. 7 of the Charter. These included ss. 9, 10, 12, 15 and para. II(c) of the Charter, para. 1(b) of the Canadian Bill of Rights. S.C. 1960, c. 44, reprinted in R.S.C. 1985. App. III and s. 96 of the Constitution Act. 1867 (U.K.), 30 \& 31 Vict., c. 3. reprinted in R.S.C. 1985. App. It. No. 5. As these claims focused on certain idiosyncratic aspects of the IRPA and not on the review of national security claims per se, a detailed review of the court's findings on each these claims goes beyond the scope of this article. Suffice to say that the judge dismissed each of the arguments, in many instances for reasons similar to those discussed above. This decision was upheld by the Federal Court of Appeal, Charkaoui C.A. \#2, stupra note 166. 
sought."183 Systems of this sort are employed by Canada's chief allies, ${ }^{186}$ and have been used in other Canadian cases involving national security concerns. ${ }^{187}$

The Federal Court of Appeal, in the Charkaoui case, was sympathetic to the difficulties the ex parte process produces, noting that "[t]here is no doubt that the system, as it exists, complicates the task of the designated judge who must, in the absence of an applicant and his counsel, concern himself with the latter's interests in order to give equal treatment to the parties before him." ${ }^{88}$ Yet, the Court of Appeal held that it was for Parliament to set up such a system, not for the courts to demand it as part of minimal constitutional guarantees. ${ }^{189}$ Similar views have been expressed by the Federal Court in two other IRPA national security detention cases. ${ }^{190}$

\section{ASSESSMENT}

In the area of judicial review and its role in constraining application of the ambiguous "national security" concept, there are both positive and negative developments.

On the positive side of the ledger, Suresh does impose a bare-bottom definition of national security, at least where Charter s. 7 is triggered. Also, some Federal Court judges have resisted extending maximum deference to at least lower-level members of the executive, pointing to their own burgeoning expertise in the national security area. Also promising is the tendency of even those courts applying a highly deferential standard of review to adopt an inquisitorial approach in testing the government's evidence during closed-door proceedings. Indeed, in $I R P A$ security-related cases, several Federal Court judges have now intervened and quashed government national security decisions where the potential consequences of mistakes - deportation to torture - are high. They have done so by pointing to government failures to competently and completely review the available evidence, labelling this shortcoming "patently unreasonable." Courts have not, in other words, agreed that national security is a total carle blanche, at least when other values hang in the balance.

Justice Hugessen, at a March 2002 conference held at the Canadian Institute for the Administration of Justice entitled "Terrorism, Law and Democracy," reproduced in Memorandum of Fact and Law of Mohamed Harkat (18 November 2004), Federal Court File No. DFS-04-02.

See e.g. special attomey procedure available for the U.S. Alien Terrorist Removal Court, 8 U.S.C. $\$$ 1534 and the special advocale procedure under the Special Immigration sppeals Commission Act 1997, (U.K.). 1997, c. 68. s. 6.

The Federal Coun of Appeal in Charkooui C.A. \#2, supra note 166 at para. 123, described the process used in Ribic C.A., supra note 155, this way: "after an agreement between the parties and with the consent of the Attomey Gieneral of Canada, a special counsel was appointed with access to the prolected information. He assisted Mr. Ribic's counsel, participated in the private and in camera hearings in his place and asked the witnesses the questions which the latter wished to have clarified." Similarly, when the Seturity Intelligence Review Committee scrutinizes CSIS activities on an exparte basis in response (o a complaint, senior SIRC counsel "will cross-exumine witnesses on [the complainant's] behalf and may provide [the complainant] with a summary of the information presented in [the complainant's] absence" (Security Intelligence Review Committee, online: Complaints <www.sirc-csars.ge.ca/ complaints_making_e.html $>$ ).

Charkaoui C.A. \#2, stupra note 166 at para. 124.

Ibid. at paras. 121-26. The Charkaoui case is on appeal to the Supreme Court at the time of this writing. Re Harkat. [2005] 2 F.C. 416, 2004 FC 1717 at para. 43 et seq.: Mahjoub, supra note 121 at para. 62. 
On the negative side, Canada's judges do typically review national security decisions pursuant to a highly deferential standard of review. Words of warning from the House of Lords, the Supreme Court of Canada and the Federal Court of Canada have underscored the relative inability of courts to make national security judgment calls. While the level of deference accorded the executive branch is moderated in some instances where statutory provisions authorize more probing court review, only in the rarest instances do courts agree that they should apply their own judgment to assessing whether a threat to national security exists. Indeed, courts interpreting the Immigration and Refigee Profection Act have sometimes demonstrated deference even when the language of the statute supports a more probing review. Meanwhile, review of national security-related issues is often conducted in camera and on an ex parte basis. To date, this secretive process has survived legal challenges brought with reference to Charter s. 7 , and the Supreme Court in Suresh clearly envisaged an approach to fundamental justice procedural protections quite accommodating of government security claims. The result is, as Sossin has warned, a sense that procedural fairness is a "luxury that may be discarded in difficult times."

\section{Conclusion}

This article suggests that national security is not a magic incantation for government, deployed to displace court oversight of government activities. Courts, like government itself, struggle to find the right balance between close oversight and impunity. The record to date is, however, mixed. The analysis in this article points to three specific problems with the concept of national security in Canadian law: first, the term is too often undefined in the statute law; second, government resort to this undefined term is typically reviewed pursuant to a highly deferential standard of review; last, this deferential review of an undefined term takes place outside the regular, open, adversarial system. Too olten, judicial review of national security decisions in Canada is a process in which deferential judges meet with government lawyers and intelligence experts in the absence of an adversarial party, to review secret information not disclosed to that adversarial party, and decide whether national security (whatever that may be) is at issue.

Remedying these problems is not an insurmountable task. First, some measure of deference in reviewing the excrcise of government national security powers may be inevitable. However, deference coupled with an ambiguous understanding of "national security" is unnecessary. There is no reason why the definition of national security in Canada's laws could not be standardized, correcting the key complaint in Parts II and III of this article. A logical starting point would be to follow an already existing pattern and link use of the term national security (and its similes) to the definition of "threats to the security of Canada" in the CSIS Act. This would have two salutary effects. First, it would provide a necessary metre stick against which to measure the legitimacy of national security justifications in the many statutes that lack a definition of the term. Second, it would standardize and centralize the understanding of national security throughout Canadian federal law. Debate could then focus on the adequacy of this standardized and centralized definition, and not be distracted by questions of whether national security might be approached differently in the other, sometimes obscure circumstances in which statutes invoke it. 
Second, there is such a thing as too much deference. The Federal Court, and on appeal, the Federal Court of Appeal and the Supreme Court of Canada, should be prepared to acknowledge the burgeoning expertise of "designated" Federal Court judges in reviewing intelligence information. As Sogi suggests, under the administrative law pragmatic and functional test, greater heed should be given to the expertise of these judges in scrutinizing national security decisions. The net result should be review of government national security claims on a standard of at least reasonableness simpliciter where there is no statutory guidance on the appropriate standard, and correctness where statutes signal that the judge himself or herself must be satisfied a national security matter is in play.

Third, the willingness of courts to probe aggressively government evidence presented in camera and ex parte may not suffice, as Hugessen J.'s complaints - cited above - suggest. Although the Federal Court of Appeal has discerned no constitutional necessity for such an approach, a security-cleared special advocate process in national security cases would constitute a significant improvement to the current Canadian system. As Hugessen J. argued persuasively in his speech on the IRPA process, the "adversary system ... is ... the real warranty that the outcome of what we do is going to be fair and just."192 For his part, then-Justice Minister Irwin Cotler, appearing before the special Senate committee reviewing Canada's anti-terrorism law in February 2005, expressed little enthusiasm for the idea. ${ }^{193}$ However, in his March 2005 appearance before the Commons committee studying the same issue, he expressed greater receptivity, indicating that the government was open to "consider the idea."

For defenders of the status quo, these solutions may be overkill. In this author's experience, government officials often dismiss critiques like the ones levelled in this article, suggesting that a focus on effective oversight ignores the bona fides of government motivations in applying Canada's security laws. This response attracts two points in rebuttal. First, while no final report has been issued at the time of this writing, evidence adduced before the Arar Commission suggests that some government officials adopt an "ends justifies the means" approach to national security, one that potentially imperils individual liberties and the rule of law. Put another way, suspicion of government bona fides may be a reasonable response to experience. Second, as a point of principle, a nation's laws should always be crafted to anticipate and curb the excesses of the worst of governments, and not leave good governance dependent on the good faith of the best of governments.

With this last point in mind, it is true the three changes proposed here would not fully dispel the concerns with the "national security" concept reflected in Senator Proxmire's statement, cited in the introduction above. They would, however, constitute a reasonable first step in policing a concept that is both legally potent and yet remains dangerously inchoate.

19: Hugessen, supra note 185.

193 Proceedings of the Special Senate Committec on the Anti-tertorism Act, Issuc 2 - Evidence (21 February 2005) 38th Parl., Ist Sess., online: <www.parl.gc.ca/38/1/parlbus/commbus/senate/com-e/ anti-e/02cv-e.htm>.

14. Subcommittee on Public Safety and National Security of the Standing Committee on Justice, Human Rights, Public Safety and Emergency Preparedness, Evidence, (23 March 2005), 38th Parl., 1st Scss., online: <www,parl.gc.ca/lnfocomDoc/38///SNSN/Mcetings/Evidence/SNSNEV08-E. HTM>. 